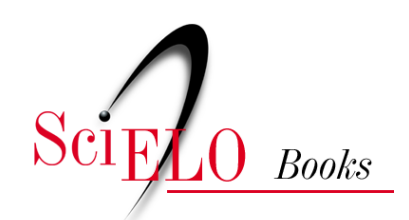

\title{
A mulher e o humor a pedra de Sísifo não cria limo
}

\author{
Alba Valeria Tinoco Alves Silva
}

\section{SciELO Books / SciELO Livros / SciELO Libros}

SILVA, A.V.T.A. A mulher e o humor: a pedra de Sísifo não cria limo. In: Deus e o diabo no humor das mulheres: contos, casos e crônicas com humor escritos por mulheres [online]. Salvador:

EDUFBA, 2015, pp. 49-99. ISBN: 978-85-232-1868-3. https://doi.org/10.7476/9788523218683.0004.

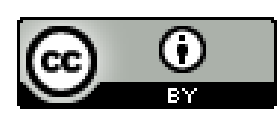

All the contents of this work, except where otherwise noted, is licensed under a Creative Commons Attribution $\underline{4.0 \text { International license. }}$

Todo o conteúdo deste trabalho, exceto quando houver ressalva, é publicado sob a licença Creative Commons Atribição 4.0. 
,

\section{A mulher e o humor: a pedra de Sísifo năo cria limo}

A mulher pode ser definida como um homem inferior. Aristóteles (Filósofo grego, 384-322 a.C.)

As mulheres em geral não apreciam arte alguma, não as conhecem e não têm talento nenhum. Jean-Jacques Rousseau (Filósofo suíço, 1712-1778)

[A mulher] sofre de uma miopia intelectual que lhe permite, por uma espécie de intuição, ver de uma maneira penetrante as coisas próximas; o seu horizonte, porém é limitado, escapa-lhe o que está distante. Arthur Schopenhauer (Filósofo alemão, 1788-1860)

Uma mulher que exerce sua inteligência torna-se feia, boba e macaca. Pierre-Joseph Proudhon (Sociólogo francês, 1809-1865)

A diferença fundamental entre as faculdades intelectuais de ambos os sexos é folgadamente comprovada pelos resultados obtidos, sempre que superiores nos homens, seja qual for o nível de dedicação, tanto quanto eram requeridos sagacidade, razão e imaginação, ou o mero uso dos sentidos e das mãos. Charles Darwin (Fisiologista inglês, 1808-1882)

Dizemos que as mulheres têm menos interesses sociais que os homens e que entre elas a faculdade de sublimar os instintos torna-se mais débil. Sigmund Freud (Psicanalista austríaco, 1856-1939)

A conspiração masculina não pode explicar todos os fracassos femininos. Estou convencida de que, mesmo sem restrições, jamais teria havido algum Pascal, Milton ou Kant femininos. Camile Paglia (Escritora americana, 1947) ${ }^{111}$

111 FERRAZ, S. (Org.). Dicionário machista. 2 ed. Londrina, PR: Campanário, 2002. Grifo nosso. 
Essas são algumas, entre outras dezenas de frases do gênero, compiladas por Selma Ferraz, no Dicionário Machista. A inserção de meia dúzia delas como epígrafe deste capítulo serve para mostrar como, ao longo da história, em diversos campos de atuação, apesar das evidências do que a mulher faz, há sempre quem o negue ou, caso se admita que ela o faz, há sempre quem se apresse em fazer a ressalva de que ela não faz bem o bastante. Relutou-se, na verdade, em inseri-las porque a leitura contínua dessa enfiada de pérolas da misoginia milenar causa um certo desconforto. Todas soam tão datadas, tão cafonas no seu machismo embolorado, que é difícil acreditar que ainda continua vigente o costume de fazer afirmações do tipo; "[as mulheres] podem muito bem passar sem o incrível senso de humor típico de nós homens", frase do colunista Fabio Hernandez ${ }^{112}$, autor do blog O homem sincero da revista Época, em seu texto As mulheres não são engraçadas. Inspirado no artigo de Christopher Hitchens, Por que as mulheres não são engraçadas ${ }^{113}$, que será comentado mais adiante neste capítulo, Hernandez ${ }^{114}$ afirma que, nos Estados Unidos, "a lista das comediantes mulheres talentosas não preenche os dedos de uma mão". E quanto ao Brasil, ele se pergunta: "Que comediante realmente brilhante a televisão brasileira produziu? E o cinema? E a imprensa?”. E, em seguida, passa a citar os nomes dos humoristas que ele considera geniais: Péricles, alguns caras do Pasquim, Zé Simão, Chico Caruso, Chico Anysio, Golias, Zeloni, os caras do Casseta. E desafia quem achar que ele não tem razão a "atirar pedras", mas "só com argumentos e mais que isso nomes".

O fato de o autor estar tão interessado no humor das mulheres no Brasil e não mencionar um nome sequer suscita conjecturas. Por que será que ele não citou entre as comediantes brasileiras (ou que atuam como comediantes): Berta Loran, Dercy Gonçalves, Nair Belo, Zezé Macedo, Cláudia Rodrigues, Regina Casé, Maria Clara Gueiros,

112 HERNANDEZ, F. As mulheres não são engraçadas. Época, São Paulo, n. 518, 19 abr. 2008. Disponível em: <http://revistaepoca.globo.com/Revista/Epoca/>. Acesso em: 5 jun. 2008.

113 HITCHENS, 2007.

114 HERNANDEZ, 2008. 
Marisa Orth, Ingrid Guimarães, Heloísa Perissé, Márcia Cabrita, Fabiana Carla, Tatá Werneck? Por que será que, mesmo sendo colunista de uma revista semanal, ele nunca se deparou com Patricya Travassos, Leila Ferreira, Gisela Rao, Fernanda Young? Por que será que, mesmo escrevendo para a internet, ele nunca ouviu falar em Cibele Santos e Pryscilla Vieira? Certamente não é por desconhecê-las, uma vez que, sendo colunista de uma revista de circulação nacional, ele deve ser uma pessoa informada. É mais provável que seja uma provocação, como indicam seu desafio e sua opinião de que Hitchens ${ }^{115}$, além de ser um provocador brilhante, está certo quando diz que as mulheres não são engraçadas.

Afirmações como as de Hernandez e Hitchens são comuns nos estudos sobre a relação entre a mulher e o humor, sendo que a recorrência dessa espécie de "São Tomé" da capacidade humorística das mulheres é apenas um dos obstáculos que elas têm enfrentado no seu processo de afirmação, como este capítulo pretende, ainda que parcialmente, mostrar.

\section{Questões sobre a relação entre a mulher e o humor}

Para além do tema comum, humor de mulheres, os estudos utilizados para a confecção deste capítulo, principalmente os de Regina Barreca ${ }^{116}$, Gail Finney ${ }^{117}$ e Nancy Walker ${ }^{118}$, possuem alguns aspectos em comum que também se fazem presentes neste trabalho, quais sejam:

a. A adoção do termo "humor produzido por mulheres" ou "humor escrito por mulheres" em lugar de humor feminino ou feminista;

115 HITCHENS, 2000.

116 BARRECA, 1988, 1996; BARRECA. R. They used to call me Snow White, but I drifted: women's strategic use of humor. New York: Penguin Books, 1991.

117 FINNEY, 1994.

118 WALKER, 1988. 
b. A impressão de estar lidando com um tema pouco explorado no meio acadêmico e cultural onde o trabalho está sendo desenvolvido;

c. A utilização de alguma declaração, normalmente feita por um homem, de que as mulheres não são engraçadas e os motivos pelos quais isto acontece $\mathrm{e}$

d. A constatação de que as mulheres fazem humor apesar de todas as afirmações contrárias.

Vale ressaltar que, embora as duas primeiras e a quarta características fossem inevitáveis, a terceira não o seria necessariamente, caso o jornal Folha de S. Paulo não tivesse publicado, no Dia da Mulher de 2007, o artigo Por que as mulheres não são engraçadas, da autoria de Christopher Hitchens ambos já mencionados anteriormente, sobre a falta de talento humorístico das mulheres, justamente quando a pesquisa inicial que embasa este trabalho estava em andamento. Desta forma, portanto, este trabalho compartilha, com os estudos mencionados, as quatro características que serão comentadas ao longo do capítulo.

\section{Humor de mulheres ou humor feminista?}

O primeiro dos aspectos, como se disse, é que todos os estudos mencionados adotam expressões como women's humor, women's humorous writings, ou women's comedy para se referir ao humor escrito por mulheres, em vez de expressões como female humor ou feminist humor.

Com isso, os estudos estão, de certa forma, afirmando que humor de mulheres não é sinônimo de humor feminista, no sentido de questionar os papéis tradicionais atribuídos aos gêneros e propor a igualdade de direitos e deveres para ambos os lados. Mesmo assim, é o humor feminista que responde por uma parte significativa da expressão humorística das mulheres americanas e, às vezes, caracteriza-se por fazer uso do texto de duplo sentido para questionar 
alguma situação em que a mulher seja vista de maneira estereotipada ou esteja em desvantagem.

Os textos de Erma Bombeck ${ }^{119}$, por exemplo, costumam ser protagonizados por uma dona de casa que quanto mais se esforça, mais as coisas dão errado: os aparelhos não funcionam, as dietas não emagrecem, os filhos não obedecem. Seu objetivo, no entanto, é mostrar que o problema não é tanto a dona de casa, mas o sistema social incluindo aí a mídia -, que torna a mulher a única responsável pelo bom funcionamento da máquina doméstica e estabelece padrões impossíveis de serem atingidos. Em A marriage made in heaven or too tired for an affair, por exemplo, a narradora descreve as expectativas, a rotina, as delícias e as agruras do próprio casamento, que se desenrola de 1949 a 1992, ao longo de cinco décadas de conquistas e retrocessos do movimento feminista. No trecho abaixo, ela comenta o impacto da televisão no casamento e o papel da propaganda na ratificação da ideia absurda de que o sucesso ou fracasso da vida familiar é responsabilidade exclusiva da mulher:

O impacto da televisão no casamento foi impressionante. Não havia uma só mulher que não se sentisse ameaçada por ela. As refeições eram planejadas em torno dela. A vida social girava em torno de sua programação. O sexo era praticado nos intervalos comerciais. Mas o principal é que as nossas vidas eram pautadas pelo seu conteúdo.

Eu e as outras da minha geração ingeríamos uma dieta semanal de mulheres que passavam o dia inteiro com pérolas e meias-finas e nunca tiveram de lavar um banheiro, e de homens que chegavam em casa, afagavam o cachorro, beijocavam a esposa (ou era ao contrário) e se trocavam para o jantar.

Mas o principal é que os programas femininos - especialmente os comerciais - definiam e reforçavam nossos papéis.

A mensagem era que o sucesso ou fracasso dos nossos maridos era única e exclusivamente responsabilidade nossa.

119 BOMBECK, E. A marriage made in heaven or too tired for an affair. New York: HarperCollins, 1994. 
Se ele não tomasse seu café da manhã reforçado, ficaria debilitado e perderia clientes. Se a toalha de banho estivesse áspera, ele ficaria irritadiço no trabalho. E se Deus me livre o chefe viesse jantar e os copos não estivessem absolutamente impecáveis, ele nunca conseguiria a promoção, e tudo por nossa culpa.

Até os homens começaram a acreditar nisso. Um dia desses, meu marido me vem com uma camisa e com um tonzinho irritante: 'Benzinho, eu acho que você esqueceu de esfregar esse colarinho!'

'Ah, é!' - retruquei - 'Será que não foi você que esqueceu de esfregar o pescocinho?' 120

O segundo tipo de humor feminista confronta mais abertamente as fontes de discriminação e tende a aparecer durante os períodos de movimentos organizados feministas. Um exemplo desse tipo de humor são as paródias dos argumentos anti-sufragistas, em que a narradora inverte os papéis e utiliza as características "intrinsecamente" masculinas para mostrar que as mulheres também seriam razões suficientes para impedir os homens de votar:

Por que não queremos que os homens votem

1. Porque lugar de homem é no exército.

2. Porque nenhum homem, verdadeiramente macho, consegue resolver nada se não for através de briga.

3. Porque se os homens adotassem métodos pacíficos as mulheres perderiam toda a admiração por eles.

4. Porque os homens vão perder seu charme se envolverem-se com questões fora de sua esfera natural de interesse, como fardas, façanhas, armas e tambores.

5. Porque os homens são muitos emotivos para votar. Sua conduta nas disputas esportivas e eleitorais mostra bem isso,

120 BOMBECK, 1994, p. 21-22, tradução nossa. 
enquanto sua tendência inata para ceder à força bruta torna-os inaptos para governar. ${ }^{121}$

Embora muito do humor contemporâneo escrito por mulheres seja humor feminista do segundo tipo, muito dele é também andrógino no sentido de que tematicamente é muito semelhante ao humor escrito por homens. Enquanto no período anterior aos anos 1970, as mulheres escreviam sobre como conseguir um marido, hoje elas também escrevem sobre como conseguir um emprego ou uma vaga no estacionamento, o que afeta homens e mulheres.

Infelizmente, o movimento de liberação ainda não realizou plenamente as mudanças radicais que prega nos campos da política, economia e liberdade social, mas a entrada de um grande número de mulheres no mercado de trabalho, os métodos contraceptivos, o declínio da taxa de natalidade e as mudanças na estrutura da família aproximaram os mundos dos homens e das mulheres o bastante para tornar possível que a mulher escreva um tipo de humor que não seja voltado especificamente para as questões específicas de gênero, caso ela assim o queira.

Por essas razões é que se preferiu a adoção do termo "humor produzido por mulheres" em vez de "humor feminino". Esta decisão inspirou-se também no depoimento da escritora Rosa Montero, feito num simpósio internacional sobre a literatura de mulheres, na Universidade de Lima, em 1999. Ela diz que, quando uma escritora escreve um romance protagonizado por uma mulher, todo mundo acha que ela está escrevendo sobre mulheres, mas que, quando um escritor escreve um romance sobre um homem, todo mundo acha que ele está escrevendo sobre a humanidade. A autora afirma que não tem nenhum interesse em escrever sobre mulheres, mas sim sobre o gênero humano, que é composto majoritariamente (51\%) por pessoas de sexo feminino. E acrescenta que, por fazer parte deste grupo, a maioria de suas protagonistas pertence a este gênero, do

121 MILLER, A. Why we don't want men to vote. In: BARRECA, R. The Penguin Book of women's humor. New York: Penguin Books, 1996. p. 395. Tradução nossa. 
mesmo modo que a maioria dos protagonistas dos escritores é do gênero masculino. E, por fim, comenta que já é hora de que os leitores se identifiquem com protagonistas mulheres do mesmo modo como, por séculos a fio, as leitoras se identificaram com protagonistas homens, argumentando que este olhar mais permeável e flexível pode nos tornar a todos mais sábios e mais livres ${ }^{122}$.

\section{Humor inexistente ou humor invisível?}

Essa controvérsia, ainda vigente, sobre que nome dar ao tipo de humor que a mulher faz, por si só é um índice da complexidade das questões aqui envolvidas. A segunda característica presente nos estudos sobre o humor escrito por mulheres é justamente a expressão de um sentimento de pioneirismo, a sensação de se estar aventurando por um território inexplorado, seja do ponto de vista teórico, seja do ponto de vista da reunião de um corpus de estudo.

Nancy Walker ${ }^{123}$, por exemplo, diz que, quando iniciou os seus estudos sobre o humor, em 1979, com exceção de uma ou outra menção a Dorothy Parker, as mulheres ou não eram citadas ou eram relegadas a notas de pé de página. Pesquisadora e professora da obra de Parker, ela não compreendia por que os estudos sobre o humor americano não falavam dessa e de outras autoras como Jean Kerr ou Erma Bombeck e achava que se tratava do mesmo fenômeno de invisibilidade que já havia impedido as mulheres de serem reconhecidas em outros campos de conhecimento, como a ciência e a música. O que ela acabou por perceber é que a invisibilidade era apenas uma parte do problema, pois o que se negava à mulher era na verdade o próprio senso de humor. A presumida e lamentada incapacidade da mulher para o humor era uma constante não apenas na teoria, mas também nos textos de mulheres humoristas que afirmavam estar escrevendo humor apesar de saberem que as mulheres não eram capazes de tal feito. De Frances Whitcher, em 1840, até Deanne

122 Montero, R. La loca de la casa. Buenos Aires: Punto de Lectura, 2007. p. 156.

123 WALKER, 1988, p. ix-x. 
Stillman, nos anos 1970, as humoristas americanas fizeram humor contrariando a opinião corrente de que elas não eram capazes de fazer o que faziam.

No decorrer de seus estudos, Walker ${ }^{124}$ percebeu que, pelo menos nos Estados Unidos, o território não era tão inexplorado assim. Duas antologias de humor escrito por mulheres - The wit of women de Kate Sanborn (1855) e Laughing their way: women's humor in America de Martha Bensley Bruère e Mary Ritter Beard (1934) - já tinham sido publicadas com o propósito de refutar a premissa de que as mulheres não tinham senso de humor. A coletânea The wit of women, por exemplo, compilada por Kate Sanborn, em 1885, foi uma resposta a um comentário do crítico americano Grant White, na revista The Critic, de 1884, de que o senso de humor era uma qualidade dificílima de ser encontrada em mulheres.

De maneira similar ao que aconteceu com este trabalho, guardadas as devidas proporções, Walker ${ }^{125}$ relata que a coleta de material, a partir de antologias impressas, foi inicialmente desencorajadora. Em antologias de humor, não foi encontrada nenhuma mulher representada, e, nas coletâneas de literatura escrita por mulheres, encontrou-se a sentimentalidade da prosa e poesia das mulheres do século XIX, caracterizado por um ar de desamparo, confissões mortificantes e ânsia de amor. Apesar do tom lúgubre da maioria da literatura escrita por mulheres à época, Kate Sanborn apresentou uma coleção significativa de textos de humor de autoria feminina. O que não impediu, contudo, que os críticos continuassem negando o humor das mulheres, alegando que o seu caráter não permitia tal coisa. Tão entranhada estava a ideia de que as mulheres não eram capazes de escrever com humor que os textos eram creditados a um homem. A visão da época pode ser resumida em uma citação de Thomas L. Masson ${ }^{126}$, exaltando os talentos de Dorothy Parker, "muitas pessoas afirmam que as mulheres não têm senso de humor,

124 WALKER, 1988, p. x.

125 Ibid. p.74.

126 MASSON apud WALKER, 1988, p. 74- 75, tradução nossa. 
mas eu não duvido que haja quem lhes negue inclusive o talento de ter filhos".

Na publicação da segunda coletânea, em 1934, Laughing their way: women's humor in América, de Martha Bensley Bruère e Mary Ritter Beard, as autoras acreditam que muita coisa tenha mudado desde a primeira antologia e que não seja mais preciso negar a suposição de que as mulheres carecem de senso de humor. Infelizmente isso não é verdade. Walker ${ }^{127}$ observa que esses precedentes, por assim dizer, vão permanecer ignorados, no sentido de que não legitimam a produção de humor como uma coisa apropriada para mulheres. Como é o caso, por exemplo, da poeta Edna St. Vincent Millay, que escrevia sketches satíricos com o pseudônimo de Nancy Boyd, na década de 1920, porque receava que a sua reputação fosse associada ao humor. Um outro caso exemplar é o de Deanne Stillman, coeditora da coletânea de humor escrito por mulheres, Titters (1976), e autora de Getting back at dad (1981), uma coletânea dos seus próprios ensaios humorísticos. Stillman sempre quis escrever humor, mas achava que isto não era próprio para mulheres e por isso escrevia paródias para a revista Mad com o pseudônimo de "Dean" em vez de "Deanne".

É curioso que, na década de 1920, Edna St. Vincent Millay escrevesse humor usando um pseudônimo feminino, para proteger sua ambição maior de ser poeta, e que Deanne Stillman, nos anos 1960, disfarçasse-se em um pseudônimo masculino para escrever humor, por achar a tarefa inapropriada para mulheres. Isso mostra que o avanço no tempo não significa necessariamente um avanço nas ideias.

O problema, segundo Finney ${ }^{128}$, é que nesse ínterim houve uma mudança radical na vida e perspectiva das mulheres nos Estados Unidos por conta da Segunda Guerra Mundial e do rápido crescimento dos subúrbios, o que levou muitas mulheres americanas "de volta para a cozinha" para se realizar como esposa e mãe, negando em muitos aspectos os avanços em direção à igualdade que tinham sido conseguidos no início do século XX. A suburbanização da sociedade

127 WALKER, 1988, p. 4-5.

128 FINNEY, 1994, p. 3-4. 
americana e o fenômeno do aumento do número de mulheres perseguindo carreiras profissionais criaram a impressão de que uma nova era de liberdade para as mulheres estava de fato começando, mas o humor das mulheres escrito entre as décadas de 1920 e 1960 indica que nada essencialmente tinha mudado: no casamento em que o casal trabalhava, apenas a mulher era responsável pelas tarefas domésticas; nos anos 1950, os eletrodomésticos, teoricamente projetados para economizar tempo nas tarefas da casa, apenas aumentaram a expectativa em relação à performance da dona de casa, e o isolamento virtual das mulheres nos subúrbios promoveu o gênero do humor doméstico que mostra a mulher interagindo mais com receitas do que ideias. O tema básico desse humor pós Segunda Guerra consiste em uma narradora recontar, com certa dose de autodepreciação, suas caóticas tentativas de atingir o padrão da dona de casa ideal, ditado por mulheres mais velhas, maridos, propaganda e revistas femininas.

É só a partir da década de 1970 que as feministas americanas vão promover a revisão do cânone em praticamente todas as áreas, tentando não apenas resgatar a literatura e a experiência das mulheres, mas também desenvolver lentes mais equilibradas em termos de gênero para se enxergar não apenas a arte, mas a própria vida ${ }^{129}$.

A motivação básica das mulheres que escrevem, e das humoristas em particular, é a necessidade de ser levada a sério como uma pessoa intelectualmente capaz de perceber e expressar os absurdos, as incongruências do mundo. Como os exemplos de Edna Bombeck, Deanne Stillman e Edna St. Vincent Millay sugerem, o humor da mulher é um índice dos papéis e valores das mulheres e particularmente da sua relação com a realidade cultural americana. Ser uma mulher humorista nos Estados Unidos tem sido problemático em aspectos que estão intimamente relacionados à história das mulheres: a tensão entre intelecto e feminilidade, as esferas separadas do masculino e do feminino, o status da mulher como minoria e o poder transformador da visão feminista. Nas palavras de Frances Whitcher ${ }^{130}$ : "era uma coisa séria ser uma mulher engraçada", ela

129 WALKER, 1988, p. 5-10.

130 WHITCHER apud WALKER, 1988, p. 6-8. 
se referia não apenas à reação cultural negativa à humorista, mas também à força que impele as mulheres a tentar tirar o seu humor da nota de rodapé e levá-lo para o centro da página.

A sensação de pioneirismo para quem se embrenha nesse campo vem do fato de que a história do humor de mulheres nos Estados Unidos e sua relação com a cultura convencional daquilo que se considera próprio de mulher compartilha alguns dos elementos do próprio humor, principalmente a ironia. Apesar da publicação de uma série de antologias voltadas exclusivamente para o humor de mulheres em suas diversas manifestações em verso e em prosa, isto permanece como uma tradição invisível mesmo para aqueles que se dedicam ao seu estudo. As razões pelas quais isso acontece são complexas, fruto de uma série de fatores aparentemente desconexos dentro da história cultural americana: alguns de teor sociológico, como o surgimento da classe média, a migração em massa para os subúrbios nos anos 1950; outros de ordem política, a proibição do voto feminino até os anos 1920, a exclusão da mulher de uma série de profissões até recentemente; a hegemonia masculina no mercado editorial e também os pressupostos, de certa forma ainda vigentes, sobre a in/compatibilidade entre a mulher e o humorismo. A ironia central está justamente no fato de apesar de estarem escrevendo e publicando textos humorísticos há mais de 150 anos, ainda permanece vigente a ideia de que as mulheres não têm senso de humor. E esta tradição permanece ignorada até mesmo por mulheres humoristas que, na década de 1970, acreditavam que eram pioneiras numa área na qual não havia ainda uma tradição feminina ${ }^{131}$.

De certa forma, isso não é surpreendente, uma vez que as mulheres têm atuado em muitas profissões sem saber que estão dando continuidade a uma herança estabelecida por gerações de mulheres, herança esta que sanciona sua contribuição e permite que elas sintam-se participantes de um processo contínuo de criatividade feminina. Nos Estados Unidos, contudo, essa invisibilidade no campo literário causa estranheza pelo fato de a literatura ter sido um campo

131 WALKER, 1988, p. 8. 
no qual a participação feminina foi aceita, ainda que considerada, em muitos casos, uma literatura menor. Ela não sofreu a restrição que outras profissões sofreram, como a medicina e o direito. A questão é que o humor é diferente. O humorista vai de encontro aos valores publicamente aceitos da cultura, ele mostra que os pés dos santos são de barro, diz que não apenas o imperador está nu, mas também estão o político, o piedoso e o pomposo. Para as mulheres, tomar tal atitude significa quebrar as regras da posição passiva e subordinada, que lhes foi conferida por séculos de tradição patriarcal, e revelar as vergonhas, hipocrisias e incongruências da cultura dominante. Ser uma mulher e humorista é confrontar e subverter o próprio poder que mantém a mulher impotente e, ao mesmo tempo, correr o risco de confrontar justamente aqueles de quem ela é dependente. O delicado equilíbrio entre poder e impotência é a questão central dos temas e das formas do humor que a mulher escreve. Esta literatura tem descrito uma miríade de aspectos da vida das mulheres, empregando os estereótipos mais comuns relacionados às mulheres, justamente para ridicularizá-los e mostrar seus absurdos e o seu perigo ${ }^{132}$.

Publicado oito anos depois do livro de Walker, a compilação The Penguin Book of women's humor, de Regina Barreca ${ }^{133}$, traz na sua introdução, novamente, o registro de comentários sobre a exiguidade de páginas que, supostamente, teria um livro com humor escrito por mulheres. A invisibilidade de uma porção significativa do humor americano é um testemunho da exclusão da mulher do poder, e as próprias mensagens do humor cotidiano são frequentemente eloquentes afirmações da subordinação feminina. E acredita-se que isso, ressalvadas as devidas diferenças, valha tanto para a conjuntura americana quanto para a brasileira, onde a falta de reconhecimento da expressão humorística das mulheres é ainda mais acentuada, conforme tem sido comentado desde a introdução deste trabalho. É curioso conjecturar se este não-reconhecimento e/ou desqualificação do humor que a mulher escreve e o tratamento muitas vezes jocoso que se dá à questão, como os comentários de Fábio Hernandez

132 WALKER, 1988, p. 9.

133 BARRECA, 1996. 
comprovam, seriam tão tolerantemente aceitos caso se tratasse de um outro grupo reivindicativo qualquer.

\section{Humor negado ou renegado?}

Outra característica dos estudos sobre o humor escrito por mulheres, como se disse, é a presença de epígrafes, citações e referências a homens, escritores, críticos, filósofos ou cientistas, que afirmam e explicam categoricamente por que as mulheres não têm senso de humor. Regina Barreca ${ }^{134}$ cita William Congreves, Reginald Blyth e J. B. Priestly; Gail Finney ${ }^{135}$ cita Schopenhauer, Bergson, Freud e Reginald Blyth; Nancy Walker cita Siriol Hugh-Jones, das revistas Punch e Tatler, que diz que toda mulher espirituosa é automaticamente suspeita e, portanto, é melhor não colocar os dedos por entre as grades da jaula quando for jogar amendoim para ela ${ }^{136}$.

Pelo visto, há mais de cem anos de declarações documentadas tentando negar a compatibilidade entre mulher e humor, e outros tantos de estudos e antologias tentando afirmar que eles são compatíveis. E ao que parece sempre vai aparecer um novo porta-voz para anunciar a impressionante falta de humor das mulheres. O arauto da vez, como se vem anunciando, é o escritor inglês Christopher Hitchens. No artigo Por que as mulheres não são engraçadas?, ele afirma textualmente que as mulheres não têm senso de humor e arroga para si a tarefa de explicar por que razão isto acontece ${ }^{137}$.

Antes mesmo de tentar questionar a pertinência de quaisquer dos motivos enumerados por Hitchens, e a maioria deles é bastante questionável, o artigo em si, o esforço empreendido já leva a perguntar: por que o riso da mulher incomoda tanto? Se de fato a mulher não tem senso de humor, se ela é incapaz de perceber o ridículo das coisas, se o seu riso é apenas um reflexo amestrado para agradar

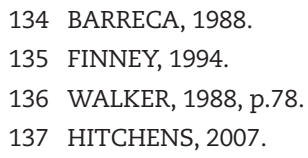


o homem, por que sairia Hitchens dos seus cuidados para negá-lo com tanta veemência? A impressão que se tem é de que, depois de conquistadas a consciência, a inteligência, a liberdade sexual etc., o humor é uma espécie de novo eterno bastião que as mulheres vão precisar escalar para fazer jus ao direito de saber e fazer rir.

Mencionando, explicitamente, por duas vezes, que o humor é sinal de inteligência, e dizendo que a mulher é mais terna, romântica, mística, sentimental, impressionável, o autor parece estar querendo negar a ela um velho direito há muito conquistado: o de raciocinar. Justiça seja feita a Hitchens ${ }^{138}$, no entanto, porque no ímpeto de diminuir o cérebro feminino, ele também minimiza o capital órgão masculino, quando diz que a natureza equipou os homens com armamentos muitos parcos para impressionar o sexo oposto. E já que esta, segundo ele, é a principal tarefa que um homem precisa desempenhar na vida, a solução é fazer a dama dar risada.

Foi a necessidade de fazer o sexo feminino rir, continua Hitchens $^{139}$, que ajudou a desenvolver o senso de humor dos machos, sendo estes, em média e como um todo, mais divertidos do que as fêmeas, porque eles não têm outra saída senão ser engraçados. Entre os elogios que se fazem ao homem, figura a capacidade histriônica. Entre as ofensas que se podem dirigir a um homem - ser ruim de cama, de trabalho e de direção -, a pior de todas é dizer que ele não tem senso de humor. A mulher, por ter o mundo a seus pés, não tem necessidade de ouvir tal coisa.

O artigo cita, como prova dos argumentos do autor, uma pesquisa, realizada na Universidade de Stanford, em que foram mostradas 70 charges a 10 homens e 10 mulheres, cujos resultados indicaram que: "As mulheres pareceram ter menos expectativa de recompensa, que, no caso, era a parte final da piada. Assim quando chegavam a essa parte ficavam mais gratificadas com ela" ${ }^{140}$. Donde Hitchens conclui que as mulheres demoram mais a entender a piada, ficam mais gratificadas quando isto acontece e são mais rápidas em identificar

138 HITCHENS, 2007, p. E4.

139 Ibid., loc. cit.

140 Ibid., loc. cit. 
o que não acham engraçado. E, por fim, comenta que, se elas têm dificuldade em entender as piadas, não surpreende que sejam menos capazes de fazê-las, embora não sejam totalmente destituídas de humor, afinal se elas não se sintonizassem com ele como poderiam rir das piadas masculinas?

Como o artigo não traz nenhum exemplo das charges que foram utilizadas nas pesquisas, a impressão que se tem é que o autor está tirando conclusões apressadas. Supondo que, no tal estudo mencionado por Hitchens, as charges escolhidas correspondam a uma amostra significativa do universo de piadas correntes na sociedade sobre a relação entre os gêneros, boa parte delas terá provavelmente conotações machistas. Sendo assim, o fato de as mulheres terem menos expectativa de recompensa no final da piada pode não ser devido à falta de entendimento, mas ao fato de serem elas particularmente o alvo de muitas dessas charges.

Corroborando a impressão de que as conclusões de Hitchens parecem ser tendenciosas, vale citar um estudo, intitulado Explorando paradigmas: o estudo de gênero e senso de humor perto do final do século 20, realizado por Lampert e Ervin-Tripp ${ }^{141}$. Os pesquisadores iniciam o artigo criticando algumas pesquisas da área de ciências sociais que, para realizar estudos comparativos entre duas populações em busca de diferenças genuínas entre elas, acabam escolhendo métodos que, na melhor das hipóteses, distorcem as diferenças e, na pior, criam aparência de diferença onde na verdade não existia nenhuma.

A crítica não é apenas sobre a falta de rigor da pesquisa, mas sobre o fato de que a escolha do método e dos paradigmas da pesquisa já molda o seu resultado final sem que os responsáveis se deem conta disso. Os pesquisadores acrescentam que isso é um problema evidente no estudo do humor, particularmente no estudo das diferenças de gênero na apreciação do humor. E especialmente problemático, segundo eles, é o corpo de pesquisa sobre o humor dos gêneros que

141 LAMPERT, D. M.; ERVIN-TRIPP, S. M. Exploring paradigms: the study of gender and sense of humor near the end of the 20th century. In: WILLIBALD, R. (Ed.). The sense of humor: explorations of a personality characteristic. Berlin: Mouton de Gruyter, 1998. p. 231-270. 
se baseia na apresentação de piadas e cartuns impressos a homens e mulheres, em ambiente de laboratório, para ver se as preferências diferem em relação ao humor, principalmente em relação a temas relacionados à sexualidade e à agressividade ${ }^{142}$.

Esse tipo de pesquisa, segundo o artigo, traz uma série de problemas, entre os quais os mais sérios são: a falta de contexto social, o uso de material não representativo, a ausência de um paralelo entre o humor em público conduzido pela pesquisa em laboratório e o humor privado utilizado por homens e mulheres no seu discurso do dia a dia ${ }^{143}$.

Os autores explicam que o principal problema em relação à falta de contexto social é o fato de que, embora homens e mulheres divirjam em sua apreciação das piadas de laboratório, a razão principal para a divergência pode não ter nada a ver nem com as diferenças na apreciação pessoal do tema e nem na estrutura da piada em si, mas sim com o fato de que - como Freud percebeu há cem anos - o significado da piada é frequentemente construído dentro de um contexto social e, sem este contexto, homens e mulheres são forçados a confiar em sua experiência prévia para guiar o seu entendimento. $\mathrm{Na}$ medida em que a experiência de mundo de homem e de mulher é diferente, os dois sexos diferem na sua apreciação da piada, não simplesmente porque um grupo gosta dela mais do que o outro, mas porque, de fato, eles estão lendo duas piadas diferentes ${ }^{144}$.

Para se ter uma ideia do que isso significa, vale citar uma experiência, mencionada no mesmo trabalho, em que grupos de homens e mulheres narram suas piadas favoritas. Entre as mulheres, uma das favoritas era: "Mary Jane vinha andando pela rua quando apareceu um cara e mandou que ela tirasse a roupa. Mary Jane caiu na risada porque sabia que sua roupa não ia dar pra ele". Segundo o estudo, pelo fato de as mulheres serem mais conscientes dos perigos de um estupro, esse tipo de piada faz com que elas riam dos seus medos e simbolicamente controlem uma situação que de outra

142 LAMPERT; ERVIN-TRIPP, 1998, p. 232.

143 Ibid., p. 232.

144 Ibid., p. 232. 
forma seria incontrolável. Já os homens acham essa que esta piada é simplesmente uma tolice e preferem aquelas que lidam com o medo da castração, como esta:

Um cara acorda de manhã com um gorila no telhado, liga pro zoológico e fala: 'Meu amigo, tem um gorila no meu telhado'. O encarregado responde: 'É, ele escapou ontem à noite, mas o senhor não se preocupe que eu já estou mandando alguém aí pra resolver o problema'. Chega o guarda do zoológico na casa do cara com uma jaula, um cachorro, um porrete e uma espingarda e diz: 'Olha, eu vou subir no telhado e derrubar o gorila com o porrete, o cachorro vai agarrar ele pelo saco e arrastar pra dentro da jaula, aí você corre e fecha a porta da jaula, ok?' O cara responde: 'Tá, mas pra que a espingarda?'. O guarda diz: É pro caso do gorila me derrubar primeiro, aí você atira no cachorro'145.

Nesse caso, segundo a experiência, as mulheres nunca se identificam com o guarda e tendem a simpatizar com o gorila ou dizer que não entenderam a piada ${ }^{146}$.

Tendo como objetivo mostrar os muitos fatores que podem interferir na compreensão de piadas e, com isto, contra-argumentar a ideia que as mulheres sejam menos capazes de entendê-las, essa digressão também explica, de certa forma, por que os homens também encontram dificuldades em entender o humor que as mulheres fazem. Só que em vez de admitir esta dificuldade, muitos preferem desqualificá-lo. É o que Hitchens ${ }^{147}$ faz quando afirma que, embora algumas mulheres sejam capazes de ser grandes humoristas, há mais humoristas mulheres péssimas do que humoristas homens péssimos.

A opinião dos críticos, mencionados até este ponto do trabalho, quanto ao humor feito pelas mulheres suscita a ideia de que ele é trivial, tolo, indigno de atenção séria, não chegando, enfim, aos pés daquele escrito pelos homens - e caso ele seja realmente bom, então

145 LAMPERT; ERVIN-TRIPP, 1998, p. 248

146 Ibid., loc.cit.

147 HITCHENS, 2007, p. E4. 
é sua autora que deve ter algum problema. Esta desvalorização, por parte dos homens, do humor feito pelas mulheres se dá por duas razões mais ou menos óbvias. Uma delas, ratificada pelo artigo de Lampert e Ervin-Tripp ${ }^{148}$, é que muitas vezes o texto da mulher é analisado a partir do gosto, dos critérios e do cânone masculino. A outra, ratificada pelas ideias de Barreca ${ }^{149}$ e Montero ${ }^{150}$, é que as mulheres escrevem fora do local de poder e autoridade e tratam de temas do seu cotidiano, como menstruação, gravidez, parto, filhos, marido, sexo. Coisas que, para os críticos, parecem desprovidas de propósito.

Partidário de uma espécie de noção de que "se a mulher é normal, o humor é péssimo, e se o humor é bom, então a problemática é a mulher", Hitchens ${ }^{151}$ diz que a maioria das boas humoristas ou é gorda, ou é lésbica, ou é judia, ou as três coisas juntas. Segundo ele, as lésbicas querem o mesmo que os homens: conquistar as mulheres. E o humor judeu, autodepreciativo e angustiado, é quase masculino por definição.

Para além do politicamente incorreto da afirmação, ela é, particularmente, curiosa, porque a recíproca pode ser verdadeira. Os humoristas homens não são exatamente modelos de beleza (basta pensar em Os Três Patetas, Danny de Vito, Woody Allen, no contexto de Hitchens, e Jô Soares, Costinha, Os Trapalhões, num contexto mais local); muitos deles, no contexto de Hitchens, são judeus, e um recurso usado à exaustão pelos humoristas do sexo masculino, de quase qualquer contexto, é o de imitar os trejeitos mais estereotipadamente afetados dos gays.

Quanto à autodepreciação, isso também é considerado uma das marcas do humor escrito por mulheres, como pode ser exemplificado pelas observações de Leila Ferreira ${ }^{152}$ :

148 LAMPERT; ERVIN-TRIPP, 1998.

149 BARRECA, 1988, p. 5-6.

150 MONTERO, 2007, p. 156.

151 HITCHENS,op. cit., p. E4.

152 FERREIRA, L. Mulheres: por que será que elas...?. São Paulo: Globo, 2007. p. 152-153. 
Do pescoço de galinha às pernas de leitoa, passando pelo bumbum articulado, as mulheres têm sido implacáveis com elas próprias. Ampliamos nossos defeitos, inventamos defeitos que não existem e, além disso, usamos um vocabulário para nos descrever que não destinaríamos a nosso maior inimigo. 'Estou uma bruxa hoje', dizemos com naturalidade. 'Comi feito uma vaca', 'estou um elefante de gorda', 'estou a cara do bonequinho da Michelin, com esse tanto de pneus', 'olha que lixo que está meu cabelo', 'estou acabadaça [...]' , 'minha pele está detonada', 'eu embagulhei depois dos quarenta', 'minhas coxas estão parecendo a superfície de Marte, de tanta celulite.' É com essa delicadeza que nos referimos a nós próprias.

Outro aspecto que Hitchens ${ }^{153}$ comenta é que o humor masculino prefere que a piada seja às expensas de alguém, enquanto o terno coração das mulheres gostaria que a vida fosse doce e justa. Nisto ele pode ter alguma razão, porque, de fato as mulheres parecem menos prontas a rir do embaraço e da dor do outro, pelo menos na vida real. Barreca ${ }^{154}$ diz que as mulheres seguem uma espécie de "regra do humor humanitário", cujo lema é evitar rir de pessoas em situações dolorosas e embaraçosas, principalmente se elas são irreversíveis. Na ficção não é bem assim, como alguns cartuns de Maitena e alguns contos de Dorothy Parker e Clarice Lispector, entre outras, podem exemplificar.

Voltando a Hitchens ${ }^{155}$, ele diz (e repete) que o humor é sinal de inteligência, e que as mulheres creem ou são levadas a crer que podem parecer ameaçadoras se aparentarem inteligência, mas faz a ressalva de que é possível, também, que alguns homens não queiram que as mulheres sejam engraçadas, porque eles as querem como plateia e não como concorrentes. Embora haja uma reserva imensa e transbordante de insegurança masculina que seria facílima de ser explorada pela concorrência - próstata, pênis, coração -, ele

153 HITCHENS, 2007. p. E4

154 BARRECA, 1996, p. 13-14.

155 HITCHENS, op. cit, p. E4 
prontamente acrescenta que isto é engraçado quando comentado pelos homens, não pelas mulheres.

"Facílima de ser explorada" é fácil de dizer. Como o próprio Hitchens ${ }^{156}$ salienta, a insegurança masculina só é cômica entre seus pares. Regina Barreca ${ }^{157} \mathrm{diz}$, na introdução de sua antologia, que a escritora canadense Margaret Atwood uma vez perguntou a um grupo de mulheres, em uma universidade, por que elas sentiam-se ameaçadas pelos homens, ao que elas responderam que tinham medo de ser surradas, estupradas e assassinadas por eles. Na vez dos homens, eles disseram que tinham medo que elas rissem deles. Não é difícil nem exagerado imaginar o risco que correm as incautas que se aventuram a explorar "a imensa e transbordante insegurança masculina".

Outro sinal da falta de humor nas mulheres, ele observa, é não saber rir da própria decadência física ${ }^{158}$. Pelo que se viu em Leila Ferreira ${ }^{159}$, algumas mulheres até que conseguem fazer isso, mas, de fato, não é fácil para mulher lidar com a aparência, talvez porque elas sejam mais cobradas neste sentido. Rugas, cabelos brancos e barrigas avantajadas são, nos homens, sinais de maturidade, experiência e prosperidade. Nas mulheres, tais características costumam ser atribuídas a decadência, velhice e desleixo.

Hitchens ${ }^{160}$ atribui à proximidade entre as funções reprodutoras e eliminatórias a origem de talvez 50\% de todo o humor. Os homens, diz ele, riem mais de obscenidades, sujeiras e coisas estúpidas, eles preferem um humor chulo e infantil, no que ele pode ter alguma razão. Barreca ${ }^{161}$ comenta que deve haver alguma relação cromossômica entre masculinidade e gostar de Os Três Patetas ou de comédias como Porkys e American Pie.

É perfeitamente compreensível que as pessoas tenham preferências distintas em termos de humor, há quem adore as Videocacetadas,

156 HITCHENS, op. cit, p. E4.

157 BARRECA, 1996, p.7.

158 HITCHENS, op. cit., p. E4.

159 FERREIRA, 2007, p. 152-153.

160 HITCHENS, op. cit.

161 BARRECA, 1991, p. 7. 
há quem não entenda o humor de Sex and the city, e quem não viva sem Zorra Total e A praça é nossa. Surpreendente seria que, entre os sexos e justamente no humor, não houvesse diferença de gostos e preferências. O problema é que onde há "humor diferente", Hitchens ${ }^{162}$ fala em "humor inferior": "A explicação do engraçado superior dos homens é mais ou menos a mesma do engraçado inferior das mulheres. Os homens precisam fazer de conta que não são os criados. As mulheres, essas astutas, precisam fazer de conta que não são quem manda de fato."

O que se pode deduzir daí é que os homens se divertem para fingir que mandam, e as mulheres se aborrecem para fingir que não mandam. Qual é a lógica desse raciocínio? Que astúcia é essa? Por que as mulheres aceitariam um jogo em que elas perdem duas vezes? E de onde vem essa ideia da qual Hitchens é partidário de que as mulheres não têm senso de humor?

De onde vem o mito da falta de humor das mulheres?

O debate sobre o senso de humor das mulheres está intimamente ligado ao debate geral sobre a sua capacidade intelectual, que ocupou educadores, pesquisadores e cientistas no século XIX. A separação entre as esferas masculinas e femininas, à medida que o século progredia, foi acompanhada por uma ênfase na diferença entre as competências femininas e masculinas de pensar e raciocinar. A lógica, a razão e o pensamento analítico se tornariam províncias masculinas enquanto à mulher foram atribuídos a intuição, o sentimento e a moralidade. As duas idealizações prevalentes da mulher do século XIX, a mulher espiritual e a mãe-terra, eram igualmente desprovidas de intelecto; quer ela levasse o homem para o plano espiritual ou telúrico, as funções e a natureza femininas continuavam intocadas pelo intelecto ${ }^{163}$.

162 HITCHENS, op. cit, p. E5.

163 WALKER, 1988, p.80. 
Há uma série de outros fatores que interferem nesse debate, e alguns estudiosos, buscando argumentos para corroborar a ideia de que a mulher é menos afeita ao humor, vão buscá-los nas mais diversas áreas do conhecimento humano, da teoria psicanalítica freudiana aos estudos linguísticos.

Dos estudos linguísticos, Walker ${ }^{164}$ cita os achados do linguista Robin Lakoff, a partir de pesquisas realizadas em meados dos anos 1970, segundo os quais a mulher sofre discriminação linguística de duas formas: no modo como são ensinadas a usar a língua, evitando palavrões e usando uma linguagem mais polida, e na maneira como são tratadas pela língua.

No caso da língua portuguesa, entre as formas de tratamento pejorativo dado à mulher, registradas no Aurélio Séc. XXI, podem ser citados, por exemplo, o fato de que os termos que designam os animais, no masculino, como galo, touro, cão, normalmente têm uma acepção positiva, enquanto os seus equivalentes, no feminino, galinha, vaca, cadela, têm acepções negativas, associadas à mulher, qualificando-a como leviana e promíscua.

Um fenômeno parecido acontece com alguns compostos formados a partir da palavra mulher, como mulher da vida, mulher da rua, mulher pública, todos com conotações negativas, enquanto seus equivalentes no masculino têm conotações positivas ou neutras: homem da rua, homem da vida, homem público.

Caso curioso é o da palavra sujeito que, no Aurélio Séc. XXI, possui vinte acepções, três das quais relacionadas à filosofia que o definem como "[o indivíduo] que é capaz de propor objetivos e praticar ações", "o que conhece", "o agente", "a fonte de atividade". Contra apenas uma acepção da palavra sujeita, que é apenas "a mulher indeterminada, ou cujo nome se quer omitir", e cuja abonação não é exatamente um exemplo de neutralidade: "saiu de casa, andou pela capital como marceneiro e depois voltou com uma sujeita ruiva que usava uns vestidos escandalosamente decotados". ${ }^{165}$

164 WALKER, 1988.

165 FERREIRA, A. B. H. Novo Aurélio século XXI: o dicionário da língua portuguesa. 3. ed. Rio de Janeiro: Nova Fronteira, 1999. 
Essa discriminação linguística seria, ainda de acordo com Lakoff ${ }^{166}$, a razão pela qual as mulheres não fazem piadas, não sabem contá-las, não conseguem entendê-las e pela qual, portanto, elas não têm senso de humor.

Não se vão repetir para Lakoff os contra-argumentos já utilizados para Hitchens, mas vale a pena ressaltar o fato de que muitas dessas piadas têm cunho machista. Ora, se a própria mulher é o alvo preferencial da punch line, ela pode ter problemas não em entender a piada, mas com a piada em si. O caráter pejorativo de muitos estereótipos femininos nela veiculados, como a resmungona, a megera, a fofoqueira, a encrenqueira, a dominadora do marido, a burra, justifica a resistência da mulher em rir. Ela pode estar querendo mostrar que não quer ser cúmplice da sua própria derrisão.

Voltando a Walker ${ }^{167}$, ela afirma que alguns pressupostos da teoria psicanalítica também são utilizados para justificar uma maior propensão do homem ao humor. Entre esses estudos, ela menciona um artigo da década de 1930, cujo autor, Alfred Winterstein, utiliza como primeira premissa para tais conclusões, a diferença, proposta por Freud, quanto à formação do superego feminino e masculino. Segundo, grosso modo, a teoria freudiana, o superego é o herdeiro do complexo de Édipo e se forma a partir de um duplo movimento psíquico: a renúncia ao amor edípico e o retorno de uma parte da libido ao próprio eu, na forma das identificações maternas e paternas e da formação dos ideais ${ }^{168}$. O menino sai do Édipo ao descobrir a falha no sexo da mulher, quando nele se cristaliza o complexo de castração. No caso da menina, ao descobrir a falha no sexo da mãe, ela reorienta o seu amor para o pai, entrando, assim, no Édipo (ou seja, na segunda fase de amor edípico ao pai) sem que exista uma ameaça que a faça sair, já que não tem mais nada a perder. Por conta desta falta de resolução, considera-se que haja uma falha na formação do superego feminino. Diferentemente dos homens, para os quais o processo é

166 LAKOFF apud WALKER, 1988, p. 86.

167 WALKER, 1988, p. 82-83.

168 FREUD, S. O ego e o id e outros trabalhos. Rio de Janeiro: Imago, 1996b. (Edição standard brasileira das obras psicológicas completas. v. 19). 
mais definido, o que os torna reféns da ameaça de castração e, por conseguinte, das exigências do superego ${ }^{169}$.

Como segunda premissa, o artigo utiliza o texto de Freud ${ }^{170}$ sobre o humor, definido como o "triunfo do narcisismo", que acontece quando o ego do humorista se recusa a sofrer, sorrindo de suas agruras, graças a um controle momentâneo do superego. Dessas duas premissas, o mesmo estudo conclui que, por estarem mais sujeitos às exigências do superego, os homens teriam mais necessidade de alívio humorístico e, portanto, seriam mais aptos a fazê-lo ${ }^{171}$.

Seguindo essa mesma linha de raciocínio e usando as mesmas premissas, uma pergunta poderia ser aqui formulada: se, para que o humor aconteça, é necessário "o superego condescender em capacitar o ego a obter uma pequena produção de prazer"172 e se, nas mulheres, por estarem menos sujeitas à ameaça da castração, o superego seria mais leniente, elas não seriam, então, mais aptas ao humor?

Talvez a questão não seja tão simples assim. Discutindo o tema do Édipo feminino, em um texto homônimo, contido no ensaio A mulher e a lei, Maria Rita Kehl ${ }^{173}$ diz que a disparidade das ameaças que pairam sobre o homem e a mulher no complexo de Édipo fez com que Freud indagasse o que forçaria a mulher a deixar de ser incestuosa, infantil, onipotente, a sair do Édipo, portanto, se ela já entra sabendo que não tem nada a perder. Esse "nada a perder", segundo Kehl ${ }^{174}$,

[...] está na origem da formação do superego da mulher, que fica assim tão complacente quanto implacável. Se por um

169 Idem. Algumas consequências psíquicas da distinção anatômica entre os sexos. In: FREUD, S. O ego e o id e outros trabalhos . Rio de Janeiro: Imago, 1996c. p. 273-277. (Edição standard brasileira das obras psicológicas completas. v. 19).

170 FREUD, S. O humor. In: FREUD, S. O futuro de uma ilusão, o mal-estar na civilização e outros trabalhos: (1927-1931). 2. ed. Rio de Janeiro: Imago, 1987.p. 165-169. (Edição standard brasileira das obras psicológicas completas, v. 5).

171 WALKER, 1988, p. 82-83.

172 FREUD, 1987, p. 169.

173 KEHL, M. R. A mulher e a lei. In: KEHL, M. R. A mínima diferença: masculino e feminino na cultura. Rio de Janeiro: Imago, 1996a.

174 Ibid., p. 44-45. 
lado é difícil ameaçar alguém com a perda de um falo imaginário, por outro este imaginário se incorpora ao próprio ser da mulher - seu falo é a feminilidade mesma, e podemos dizer que na rivalidade edípica ela não tem nada a perder a não ser [...] a feminilidade. Nada a perder a não ser tudo o que faz dela uma mulher.

É possível relacionar essa afirmação à questão do humor no sentido de que a mulher pode ter sido levada a evitá-lo ou escondê-lo pelo medo de incorrer nessa perda da feminilidade, em culturas em que a demonstração pública de humor não é considerada apropriada para mulheres.

Essa questão do que é próprio ou impróprio para uma mulher, ou melhor, para algumas idealizações da mulher, cristalizadas em noções como "menina educada", "moça de família", "moça casadoira", "mulher de bem" e "senhora de respeito", talvez seja um dos fatores mais preponderantes por trás da ideia de que a mulher é refratária ao humor.

Walker menciona estudos da área de antropologia que afirmam que, entre os vários métodos que são utilizados em diferentes culturas para controlar e determinar o comportamento das mulheres, tais como o confinamento, a proteção e o método da restrição normativa, é justamente este último o mais complexo. Apesar de parecer o mais liberal, ele na verdade deposita o fardo da obediência às restrições sociais em cada mulher individualmente, exigindo assim que ela seja a censora de seu próprio comportamento. O que está sendo chamado de "restrição normativa" (uma espécie de "superego postiço") é um conjunto de valores e expectativas culturais embutido naquelas noções de "menina educada", "mulher de bem" etc., que incluem, guardadas as devidas diferenças culturais, valores como castidade, gentileza, graça, inocência, bondade, limpeza, brandura, virtude etc. E, além de tudo isso, ela deve aceitar o que lhe dizem sem discutir e permanecer acima de qualquer suspeita ou censura. Em contraste com o confinamento (que mantém a mulher em casa) e a proteção (que exige que a mulher só saia de casa acompanhada), 
o método da restrição normativa exige que a mulher internalize o conjunto de regras que ditam o comportamento apropriado da "boa menina", e isso é para a vida toda. A condição de "mulher de respeito" nunca é totalmente atingida, ela precisa ser demonstrada em cada instância da interação social. Estar sob esta constante pressão do comportamento adequado é um fator que tem relação direta com a livre expressão do humor. Tanto é assim que entre si as mulheres costumam dar mais vazão ao seu humor do que quando há homens presentes, daí a invisibilidade do humor para os homens ${ }^{175}$.

Finney observa que, num ambiente em que prevaleça essa ideologia do que é próprio ou impróprio para a mulher de bem, como a que se estabeleceu na sociedade americana do século XIX, uma certa passividade, um certo desejo de aprovação masculina e os preceitos da etiqueta das damas são nocivos à produção de humor ${ }^{176}$. Barreca, por sua vez, salienta que este último aspecto ainda persiste na década de 1960, quando não se admitia que uma moça de família entendesse o teor sexual de alguma piada mais picante ${ }^{177}$.

Entre as consequências que esse código de conduta pode acarretar, duas são particularmente contraproducentes para o humor. Uma delas é a expectativa de que as mulheres sempre tenham bons sentimentos, ao passo que a comédia necessita de uma dose de agressividade, sátira e zombaria. A outra, inspirada em Bergson ${ }^{178}$, é que a comédia necessita do grupo para se manifestar. Estando, por muito tempo, excluída da esfera pública da sociedade, a mulher muitas vezes não esteve aí presente para compartilhar desse aspecto ${ }^{179}$.

Por tudo que se disse, conclui-se que liberdade intelectual, independência e senso de humor guardam entre si uma certa interdependência. A percepção e a criação do humor são atividades intelectuais que permitem perceber a ironia e a incongruência de uma situação e, ao mesmo tempo, mantê-las a uma certa distância para ser capaz

175 WALKER, 1988, p. 84-85.

176 FINNEY, 1994, p. 1-2.

177 BARRECA,1991, p.1-5.

178 BERGSON, 2001, p. 4-5.

179 FINNEY, op. cit., p. 2. 
de brincar. A visão humorística requer a habilidade de manter duas realidades contraditórias em suspensão simultaneamente - para executar um ato de equilíbrio mental que sobrepõe a visão cômica da vida aos fatos observáveis. A percepção do ilógico requer uma percepção prévia da lógica aceita. E aqueles que negam à mulher o senso de humor estão, na verdade, negando-lhe primeiramente sua capacidade de pensamento lógico ${ }^{180}$.

O mito da falta de humor das mulheres, que a esta altura já pode ser entendido como uma falha de percepção de quem não consegue (ou não quer) enxergá-lo, tem uma longa história e, pelo depoimento de Hitchens, está ainda longe de ser derrubado por completo. Essa falha de percepção, por sua vez, explica-se, como já se disse, principalmente porque a maioria dos estudos sobre o humor, no caso do humor americano, foi realizada a partir dos textos de um escritor homem e branco. E é curioso que, nesses textos, mesmo quando o humorista adota a postura do outsider, do homem comum ou do pobre-diabo que percebe as loucuras da burocracia ou da tecnologia, ele escreve com a autoridade do insider, da pessoa que potencialmente está na posição de mudar o que julga incorreto, sejam as leis ou a largura das lapelas. Já os escritos humorísticos das mulheres, por serem escritos fora do círculo do poder, evidenciam uma relação diferente com o status quo. Por mais absurdas que as normas vigentes pareçam, elas exercem uma força com a qual a mulher muitas vezes tendeu mais a cooptar do que a reagir. É por esta razão que o humor escrito por mulheres tão frequentemente parece ratificar e perpetuar os tradicionais estereótipos das mulheres: a solteirona, a fofoqueira, a esposa resmungona, a dona de casa inepta, a mal-amada, a loura burra ${ }^{181}$.

Muitas humoristas, contudo, tentaram mostrar que tais papéis não eram exatamente uma carapuça e tentaram subvertê-los. A dona de casa de Erma Bombeck, por exemplo, não consegue exercer o seu papel à perfeição não porque ela seja incompetente nas tarefas domésticas, mas porque os padrões impostos à "perfeita dona

180 Cf. WALKER, 1988, p. 82.

181 WALKER, 1988, p.11. 
de casa" são, simplesmente, impossíveis de serem atingidos ${ }^{182}$; as mal-amadas de Dorothy Parker assim o são porque, muitas vezes, são vítimas da indiferença masculina ${ }^{183}$; a loura burra Lorelai Lee, de Os homens preferem as louras, de Anita Loos, de burra não tem nada, sua presumida burrice é uma arma que ela usa em proveito próprio, rindo à socapa dos homens que querem "educá-la"184.

Pelas razões mencionadas anteriormente, quanto ao código de conduta adequado às mulheres, o humor das mulheres era desencorajado em público, mas, no âmbito doméstico, ele florescia. Muito desse humor permaneceu oculto e tem sido trazido a público, através do resgate de autoras de humor nunca publicadas e pelo humor descoberto no trabalho de autoras tidas como sérias como Emily Dickinson e Louise May Alcott, como será visto em Barreca, The Penguin Book of women's humor, na próxima seção ${ }^{185}$.

A dificuldade que muitas dessas obras têm em adquirir visibilidade deve-se, principalmente, ao fato de elas relatarem as experiências femininas no âmbito doméstico. O fato de a maioria das mulheres, até meados do século XX, depender financeiramente do marido ou do pai tornava-as obedientes à lei de "não morder a mão que alimenta", fazendo com que o humor produzido por mulheres que tivesse o homem como alvo fosse compartilhado em segredo. Além disso, sendo a casa o universo onde a maioria delas transitava, era sobre a família e os afazeres domésticos que o seu humor versava. Por mais engraçada que seja a comédia da vida privada, ela não consegue concorrer com a sátira do mundo masculino, que abrange o comércio, a política, o direito, os negócios ${ }^{186}$.

Aqui, é inevitável a ressalva de que a comédia da vida privada só é considerada "menor" quando escrita por uma mulher, vide o

182 BOMBECK, 1994.

183 PARKER, 1976.

184 LOOS, A. Gentlemen prefer blondes. New York: Liveright, 1998.

185 BARRECA, 1996.

186 FINNEY,1994., p. 3 
sucesso (18 edições em livro até 1996 e série da rede Globo) da obra homônima de Luis Fernando Verissimo ${ }^{187}$.

Como elas fazem humor se não sabem...?

A quarta e última característica comum que permeia, de maneira mais evidente, os estudos de humor aqui utilizados é a constatação de que as mulheres podem até não entender de humor, mas continuam a fazê-lo.

Na antologia The Penguin Book of women's humor, Regina Barreca reúne contos, cartuns, trechos de romances de autoria de escritoras de língua inglesa, cujas obras ou são diretamente humorísticas ou trazem humor de alguma forma. Na introdução da coletânea, ela diz que a apreciação e produção de humor sempre foram consideradas atividades masculinas, como escrever na neve com a urina. Rir e contar piadas não eram coisas apropriadas para mulheres, o melhor era mantê-las longe da política, do sexo e do humor. O problema óbvio é que a mulher nunca esteve a salvo de nada, mesmo tendo sido, teoricamente, mantida afastada do mundo: a caça às bruxas, a morte no parto, a opressão no trabalho não são exatamente exemplos da vida doce e justa de que fala Hitchens ${ }^{188}$. A vida da mulher, obviamente, sempre esteve relacionada ao sexo e à política. Muito do humor produzido por mulheres, quando não explicitamente político, questiona as verdades aceitas do sistema, como a crítica de Erma Bombeck à "perfeita dona de casa"189. E quando é explicitamente político, ele satiriza as forças sociais projetadas para manter a mulher no seu "devido lugar", como o exemplo do manifesto "Por que nós não queremos que os homens votem"190. Não deve (e não pode) ser surpreendente o fato de a mulher ter sempre feito uso de algum tipo de humor, principalmente como uma ferramenta de sobrevivência

187 VERISSIMO, L. F. Comédias da vida privada. 18. ed. Porto Alegre: L\&PM, 1996.

188 HITCHENS, 2007, p. E4.

189 BOMBECK, 1994.

190 MILLER, 1996. 
no mundo social e profissional e como uma arma contra os absurdos da injustiça. O fato de sua coletânea reunir cerca de 200 escritoras, do século XVI aos dias atuais, mostra que as mulheres não se tornaram subitamente engraçadas nos anos 1990, assim como não se tornaram ambiciosas nos 1970, nem sexualmente liberadas nos 1960, nem inteligentes em $1890^{191}$.

A despeito dessa rica história, muitos apostaram que um livro sobre o humor escrito por mulheres seria necessariamente fino e curto. O livro, que poderia ter o dobro das 658 páginas, só não ficou maior, segundo a autora, por conta de suas preocupações ecológicas e por alguns editores não permitirem a republicação de algumas obras ${ }^{192}$.

Apesar de plenamente capacitadas para exercer e apreciar uma variedade de talentos, sendo o humor um dentre os muitos, só recentemente as humoristas vieram a público para receber merecida atenção, risada e aplauso. De onde vêm essas mulheres engraçadas? De onde elas tiraram coragem para repelir as restrições que dizem que as boas meninas não podem rir e muito menos fazer rir? Muitas escritoras de humor e comediantes têm aparecido, há muitos trabalhos sendo descobertos e, além disso, há o humor a ser resgatado nos textos de autoras consideradas sérias, como Edith Wharton, Emily Brontë, Emily Dickinson, que não são apenas grandes e boas, mas também engraçadas ${ }^{193}$.

A conclusão irônica a que se chega é que, para que o humor das mulheres adquira reconhecimento e abrangência, é necessário que ela fale de coisas sérias. Não admira, portanto, que muito do humor feminino europeu e americano aconteça no rastro dos movimentos feministas. A luta pelo voto e pela igualdade de direitos dá à mulher um poder sem precedentes na história. E um certo senso de poder é necessário para a criação do humor, que, por sua vez, gera mais poder para quem o faz ${ }^{194}$.

191 BARRECA, 1991, p.1-5.

192 Ibid., loc.cit.

193 Ibid., loc.cit.

194 FINNEY, 1994, p.3. 
Os movimentos feministas dos anos 1960 e 1970, por exemplo, vão ajudar a subverter a posição autodepreciativa na qual a mulher se representava na comédia que escrevia até então, criando personagens mais astutas, zombeteiras, dispostas a chocar a audiência, tornando-se, enfim, o sujeito de sua própria comédia.

Entre as décadas de 1980 e 1990, por sua vez, simultaneamente ao crescente volume de comédia e crítica escrito por mulheres nesse período, surge uma espécie de consenso de que há diferenças entre o humor masculino e feminino ${ }^{195}$.

\section{Humor diferente por quê?}

Uma das primeiras humoristas americanas, Francês M. Whitcher (1814-1852), explica que o problema central da humorista nos Estados Unidos é o fato de que o humor vai de encontro ao que se considera a feminilidade ideal, nos seguintes termos: o humor é agressivo, as mulheres são passivas. O humorista ocupa uma posição de superioridade, a mulher, de inferioridade. Tendo sido repreendida na infância por sua tendência a fazer graça das coisas, ela até certo ponto esteve consciente desse paradoxo e desenvolveu uma estratégia que depois seria usada por outras humoristas: um texto que funciona em dois níveis - um que parece endossar os estereótipos sobre as mulheres e outro que aponta para a origem desses estereótipos em uma cultura que define a mulher em termo de sua relação com os homens ${ }^{196}$.

O depoimento de Whitcher mostra que as razões para eventuais diferenças no humor das mulheres são explicadas em grande parte pelas complexas atitudes provocadas pela relação da mulher com a expressão humorística. Embora a apreciação do humor masculino (desde que ele não seja indecente ou obsceno) seja considerada um traço admirável nas mulheres, a criação de humor por mulheres, seja verbal ou escrito, tem provocado muita controvérsia. Seja visto pela perspectiva da psicologia, antropologia, sociologia ou linguística, o

195 Ibid, p. 5.

196 WALKER, 1988, p. 2. 
humor está relacionado a poder, autonomia e agressão de maneiras tais que afetam diretamente a relação entre os gêneros ${ }^{197}$.

Por conta dessas diferentes formas de lidar com humor, as características que sobressaem do humor escrito por mulheres e que poderiam ser consideradas diferentes da forma como os homens o escrevem podem ser assim resumidas, de acordo com Barreca ${ }^{198}$ :

a. as mulheres preferem contar histórias engraçadas, enquanto os homens preferem contar piadas;

b. os objetivos principais da mulher são a comunicação e o compartilhamento de experiências, enquanto o homem quer aparecer e mostrar que é esperto;

c. a comédia feminina é menos hostil, as mulheres tendem a se autodepreciar mais do que desqualificar o outro;

d. o alvo do humor produzido por mulheres é mais o poderoso do que o desprezível;

e. as mulheres costumam rir menos da dor e do embaraço dos outros;

f. as histórias femininas frequentemente são não lineares; o humor das histórias está mais no reconhecimento do que na resolução, mais no processo do que na conclusão, o que se caracteriza por uma ausência de final feliz ou uma absoluta falta de desfecho;

g. a expressão humorística feminina nunca é puramente cômica ou absurda. Mesmo quando ela aponta para a miríade de absurdos que as mulheres foram forçadas a suportar na cultura americana, ela deixa transparecer não o gracejo característico dos poderosos, mas um subtexto de angústia e frustração ${ }^{199}$.

197 Ibid., loc. cit.

198 BARRECA, 1991, p. 1-37.

199 WALKER, 1998, p. xii. 
Muitos desses aspectos, tais como a falta de linearidade do enredo, falta de desfecho, autorreferencialidade, são observados por Isabel Allegro de Magalhães como tendências predominantes nos textos escritos por mulheres ${ }^{200}$.

\section{Humor igual em quê?}

Finney argumenta, contudo, que essas diferenças disfarçam outras tantas similaridades existentes entre o humor dos gêneros, entre as quais ela aponta ${ }^{201}$ :
a. o uso do grotesco para a representação do corpo risível;
b. o uso da paródia, do discurso dialógico;
c. o uso das experiências, atitudes e valores compartilhados para ridicularizar quem está fora do grupo, no sentido de que os homens riem das mulheres, as mulheres riem dos homens e ambos riem das loiras;
d. a ridicularização dos estereótipos e das normas;
e. a ridicularização de quem foge deles;
f. a troca de papéis como fonte de riso;
g. o uso de agressividade.

Sobre esse último ponto, Barreca salienta que, embora uma certa dose de raiva e agressividade seja, também, um ingrediente do humor escrito por mulheres, há uma diferença na recepção desse humor agressivo quando o autor é uma mulher. Segundo ela, quando o homem expressa raiva através do humor, isso é visto como uma

\footnotetext{
200 MAGALHÃES, I. A. O sexo dos textos: traços da ficção narrativa de autoria feminina. In: MAGALHÃES, I. A. O sexo dos textos e outras leituras. Lisboa: Editorial Caminho, 1995. p. 15-53.

201 FINNEY, 1994, p. 6-9.
} 
demonstração de presença de autocontrole, uma vez que ele poderia estar agindo de maneira destrutiva não apenas falando desta forma. Quando é a mulher quem mostra a raiva, isso é visto como uma demonstração de falta de autocontrole, porque não se espera que ela sequer tenha raiva para começo de conversa ${ }^{202}$.

O que se percebe dessas discussões sobre diferenças e semelhanças entre o humor de homens e de mulheres é que há argumentos o bastante de ambos os lados para manter a questão em aberto e sujeita ainda a muita discussão, como sugere o próprio título do primeiro capítulo da obra de Finney, Unity in difference? ${ }^{203}$

Embora já haja, pelo menos nos Estados Unidos, um contingente considerável de humor feito por mulheres e que já permite este tipo de discussão sobre semelhanças e diferenças de gênero no humor, o que se percebe também é que o processo, como de resto tudo o mais nas conquistas femininas (e humanas), continua em fase de afirmação. Tanto é assim que Barreca organiza uma espécie de manifesto da comédia stricto sensu escrita por mulheres, entre cujas ações afirmativas destacam-se $\mathrm{e}^{204}$ :

a. a adoção das convenções básicas associadas ao gênero, apresentando os sinais que distinguem a comédia de outras formas literárias;

b. o estabelecimento de uma tradição de comédia escrita por mulheres;

c. a subversão de algumas das convenções da comédia, como por exemplo, aquele final feliz em que tudo é resolvido e o herói é reintegrado à sociedade ${ }^{205}$.

Pela falta eventual de alguns desses elementos, a comédia escrita por mulheres tem sido mal interpretada e, muitas vezes, considerada

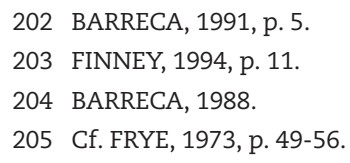


como uma não-comédia. O problema principal talvez seja o fato de que, como não se espera encontrar humor nos textos escritos por mulheres, dificilmente ele é encontrado, mas isso não quer dizer que ele não esteja lá. Embora a discussão da comédia escrita por mulheres possa ser feita à luz de uma discussão mais geral e fora das questões de gênero, isso não invalida a criação de um discurso crítico que discuta a relação específica entre a mulher e a comédia.

Como foi citado no capítulo 1, Northrop Frye classifica como cômicas as ficções literárias, em cujo enredo o herói se incorpora a seu grupo social, ocasião, não raramente, celebrada com a realização de casamentos em série para simbolizar a aceitação de todos no seio da sociedade ${ }^{206}$.

A subversão desse final conciliatório e reintegrativo, como o item "c" do manifesto sugere, é uma das características que tornam "perigosa" a comédia escrita por mulheres, pela rejeição dos limites sociais e culturais que exigem que haja um final, um fechamento. O item "c" aponta para uma recusa em se deter naquele ponto para além do qual a comédia perde a sua função reintegradora, tornando-se assim uma comédia descentradora, deslocadora, desestabilizante.

Barreca positiva essa recusa da mulher a dar um fechamento à comédia que escreve, entendendo-a como uma potencialidade e não uma fragilidade, na medida que isto indica que a sua escrita depende do processo, da experiência, e não da finalização. A experiência impede o sujeito de continuar como antes, enquanto a catarse, pelo menos dentro da comédia tradicional, permite a continuação do que era antes ${ }^{207}$.

A ressalva que Barreca faz ao fato de estar utilizando o conceito de catarse da comédia tradicional é importante, porque, pelo que já havia sido mencionado no capítulo 1 deste trabalho, a noção de catarse, tal como definida por Mendes - um processo que requer, ao mesmo tempo, a participação afetiva e intelectual do fruidor, levando a um tipo especial de aprendizagem capaz de conjugar ludicamente

206 FRYE, 1973, p. 49-56.

207 BARRECA, 1988, p. 16-17. 
sensações e conceitos, gozos e valores no todo de uma experiência ${ }^{208}$ -, justamente por nela incorporar a experiência e os afetos daí decorrentes, dificulta a separação dos seus elementos como proposto por Barreca.

Mas, feita a ressalva, procede a ideia de Barreca de que o prazer da comédia não advém da perpetuação do familiar, mas da sua destruição, uma vez que o fator surpresa é apontado como necessário ao humor desde a Antiguidade ${ }^{209}$.

Afirmando, pois, que o prazer da comédia depende das surpresas, rompimentos, inversões, desunião, desarmonia, ela acrescenta que a resolução de tensões, através da unidade e da integração, não deve ser considerada solução viável para a comédia escrita por mulheres, porque tais recursos são muito limitados para lidar com a natureza não fechada dessa escrita. E comenta que não é de admirar que esse tipo de comédia passe despercebida, ou seja, mal interpretada pelos críticos, o que implica, em sua opinião, mais a inabilidade da crítica em lidar com os textos de humor escrito por mulheres do que a inabilidade da mulher em escrever humor ${ }^{210}$.

\section{A quem interessa a falta de humor nas mulheres?}

Qual seria a razão da persistente negação do humor das mulheres? Entre as razões sugeridas para o fenômeno está o fato de que as próprias mulheres acham que não é boa política cultivar ou expressar seu humor. Qual é a mulher que quer correr o risco de ser chamada irônica e sarcástica? Isso pode afastar os homens, pode ser perigoso, pode até mesmo ser fatal, como já se comentou anteriormente, a propósito do comentário da escritora Margaret Atwood sobre o fato de que os homens têm medo de que as mulheres riam deles ${ }^{211}$. Elas muitas vezes se furtam ao duelo humorístico com o homem para lhe

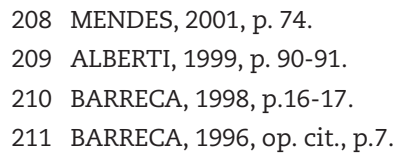


permitir um certo senso de dominação. Esta atitude das mulheres, que se relaciona ao papel de "espelho", como observa Virginia Woolf em A room of one's own, foi adotada por muitas mulheres, ao longo da história, refletindo a imagem do homem maior do que o seu tamanho natural, porque isto era necessário para que eles se sentissem capazes e superiores ${ }^{212}$.

Outra razão é a expectativa masculina em relação ao comportamento feminino: a agressividade e a superioridade, muitas vezes presentes no humor, estão em conflito com as posturas de submissão e passividade que, em muitos casos até hoje, se espera das mulheres. Em 1998, final do século XX, portanto, no filme Mensagem para você $\hat{e}^{213}$, a personagem de Meg Ryan, dona de uma pequena livraria, não consegue dar o troco, quando é provocada pelo personagem de Tom Hanks, proprietário de uma megaloja de livros que vai tirá-la do negócio. Quando finalmente, movida pela raiva, ela consegue responder à altura, se sente culpada. É como se os filmes e a televisão tivessem substituído os manuais de etiqueta do século XIX sobre o comportamento adequado das mulheres de bem e das garotas de família, mas a mensagem é a mesma: o caráter agressivo e desestabilizador da tirada humorística não é apropriado para as mulheres.

A negação do senso de humor das mulheres não é uma questão isolada ou trivial. Pelo contrário, é parte de uma complexa teia de pressupostos culturais sobre a inteligência, a competência e o lugar da mulher. À medida que a mulher é vista como apoio, objeto sexual e serva doméstica, ela não pode ao mesmo tempo ter a permissão de ter senso de humor, com sua necessária afirmação de superioridade e sua crítica fundamental à realidade social. Uma senhora de respeito e uma garota de família não são engraçadas, na melhor das hipóteses, elas apreciam o humor do marido ou do namorado. Por isso mesmo, um dos temas dominantes no humor das autoras americanas tem sido a rejeição desses estereótipos passivos e anti-intelectuais que

212 WOOLF, Virginia. A room of one's own. London: Harcourt Brace Jovanovich, [1957]. p. 35-36.

213 MENSAGEM para você. Direção: Nora Ephron. Intérprete: Meg Ryan; Tom Hanks [S.l.]: DVD Vídeo, 1998. 1 DVD (120 min.), son., color. 
negam às mulheres independência e autoestima ${ }^{214}$. Elas têm rido da absurda acusação de que são desprovidas do humor, de maneira abertamente satírica ou à socapa.

\section{A mulher e o humor no Brasil}

\section{A lacuna na teoria}

Quase dez anos depois do início da pesquisa que deu origem a este texto, a reação das pessoas à menção do tema deste trabalho reflete, talvez, a situação dos estudos sobre o humor escrito por mulheres no Brasil. Algumas perguntam se isto, o humor de mulheres, existe de fato; outras duvidam da pertinência do tema, por achar que é óbvio que as mulheres têm humor, mas sem conseguir lembrar de um nome de uma única escritora sequer; a maioria delas diz que nunca havia pensado no assunto, mas que de fato o tema dá o que pensar.

Este capítulo seria mais eficiente para o propósito deste trabalho se ele se encerrasse aqui. Há quase dez anos pesquisando sobre o humor escrito por mulheres no Brasil, não se encontrou um texto acadêmico sequer diretamente voltado para a questão central, ou seja, para a ausência de textos de mulheres nas antologias de humor no Brasil ou para a dificuldade que Fábio Hernandez, supostamente, encontrou para citar o nome de, pelo menos, uma mulher que se destaque no humor por aqui ${ }^{215}$. Não se trata de uma afirmação de efeito, foi compilada e organizada uma bibliografia de cerca de duas dezenas de volumes de estudos voltados exclusivamente para a questão da relação entre a mulher e a literatura, sendo que a maioria deles voltado para o Brasil, que vão desde O que é escrita feminina, de Lúcia Castello Branco ${ }^{216}$, até Ensaístas brasileiras: mulheres que escreveram sobre literatura e artes de 1860 a 1991, de Heloísa Buarque

214 WALKER, 1988, p. 99.

215 Cf. HERNANDEZ, 2008.

216 BRANCO, L. C. Escrita feminina. São Paulo: Brasiliense, 1991. (Primeiros passos, n. 251). 
de Hollanda e Lúcia Nascimento de Araújo ${ }^{217}$, passando pelos dois volumes dos Anais do VII Seminário Nacional de Mulher e Literatura, e muito pouco foi dito sobre a relação entre a mulher e o humor, embora isso até pudesse ter acontecido. No segundo volume dos Anais, há um artigo de Márcia Lorca Ventura, intitulado As relações entre homem e mulher dentro de discursos femininos e masculinos: um estudo comparativo de textos de Marina Colasanti e Luís Fernando Verís$\operatorname{simo}^{218}$. Esses autores são comparados enquanto dois cronistas que, como tal, observam, retratam, comentam os flashes da vida cotidiana. Como, muitas vezes, a crônica pode ser construída com a inclusão de uma certa dose de humor, esperava-se que tal abordagem fosse levada em consideração e que as eventuais diferenças no uso do recurso fossem mencionadas. Mas não é o caso, com exceção de uma espécie de crítica ao tipo de ironia que Veríssimo utiliza nas suas crônicas, o texto passa bem ao largo do humor.

Há, por outro lado, na bibliografia compilada, títulos voltados para o estudo do humor na literatura brasileira, como o de Lélia Parreira Duarte ${ }^{219}$, Ironia e humor na literatura; o de Lia Cupertino Duarte ${ }^{220}$, Lobato humorista: a construção do humor nas obras infantis de Monteiro Lobato e o de Antônio Martins ${ }^{221}$, Arthur Azevedo: a palaura e o riso. Todos versam sobre aspectos do humor nas obras de Machado de Assis, Guimarães Rosa, Monteiro Lobato, Arthur Azevedo e outros escritores brasileiros e portugueses, mas não se faz menção ao humor escrito por mulheres.

217 HOLLANDA, H. B.; ARAÚJO, L. N. Ensaístas brasileiras: mulheres que escreveram sobre literatura e artes de 1860 a 1991. Rio de Janeiro: Rocco, 1993.

218 VENTURA, M. L. As relações entre homem e mulher dentro de discursos femininos e masculinos: um estudo comparativo de textos de Marina Colasanti e Luís Fernando Veríssimo. In: SEMINÁRIO NACIONAL MULHER E LITERATURA, 7., 1999, Niterói. Anais... Niterói: Eduff, 1999. p. 579-583. v. 2.

219 DUARTE, L. P. Ironia e humor na literatura. Belo Horizonte: Ed. PUC Minas; São Paulo: Alameda, 2006a.

220 DUARTE, L. C. Lobato humorista: a construção do humor nas obras infantis de Monteiro Lobato. São Paulo: Ed. UNESP, 2006b.

221 MARTINS, A. Arthur Azevedo: a palavra e o riso. São Paulo: Perspectiva; Rio de Janeiro: UFRJ, 1988. 
O livro de Luiza Lobo, Crítica sem juízo ${ }^{222}$, traz uma seção com sete textos dedicados à transgressão e ao humor na literatura, nos quais ela analisa o uso destes recursos nos textos de Machado de Assis, Guimarães Rosa, Sousândrade, Gonçalves Dias, mas de nenhuma mulher. Nesse mesmo livro, contudo, no texto intitulado Dez anos de literatura feminina brasileira, ela aborda o assunto ao comentar, como o título indica, a produção literária da mulher brasileira, no período 1975-1985.

Lobo divide as autoras que escreveram nesse período em dois grupos principais. No primeiro, estão aquelas que se destacam no estilo, usando em seus textos a temática existencial (Rachel Jardim, Patricya Bins, Lya Luft, Hilda Hilst, Adélia Prado); a experimentação na linguagem (Nelida Piñon, Regina Célia Colônia, Lygia Fagundes Telles, Helena Parente Cunha) e a alegoria política (Edla von Steen, Myriam Campello, Heloneida Studart), "mas que não conseguem renovar seus papéis enquanto mulheres na tradição literária"223.

No segundo, estão aquelas que renovaram a voz no seu discurso, dando "ênfase ao humor e ao uso de diário, cartas, poemas sob o ângulo do erotismo"224. Nesse último grupo, estão as escritoras Ana Cristina César, Olga Savary, Márcia Denser, Sônia Nolasco Ferreira, Sônia Coutinho. No grupo daquelas que usam o humor e a ironia em seus textos, Lobo cita Márcia Denser e a poeta paulista Ledusha ${ }^{225}$. No final do texto, ela ressalta a importância do humorna literatura e na sociedade como elemento desestabilizador das estruturas e conclama a mulher a rir mais de si mesma em vez de se lastimar e, no caso da mulher brasileira, a se tornar menos Ci, mãe do Céu, que pagou por seus prazeres com a morte,e mais Macunaíma. 226

222 LOBO, L. Crítica sem juízo. Rio de Janeiro: Francisco Alves, 1993.

223 LOBO, 1993.

224 Ibid., p. 49.

225 LOBO, 1993. p.55-57.

226 Ibid., p. 61. 
Em outro texto de Luiza Lobo sobre literatura feminina na América Latina, ela diz que uma das características dos textos de Clarice Lispector é o uso do humor sutil e da ironia ${ }^{227}$.

$E$ isso resume os achados sobre o assunto. Obviamente que o fato de não ter encontrado referências teóricas significativas sobre o assunto no Brasil pode ser uma deficiência da pesquisa, mas é possível também que o estado da arte desse tema, por aqui, esteja na fase em que ele se encontrava por volta de 1885 nos Estados Unidos: o primeiro livro ainda estava por ser escrito, a primeira antologia de humor escrito por mulheres ainda estava por ser compilada. Não se quer dizer com isso que os estudos sobre o humor escrito por mulheres no Brasil estejam "atrasados" em relação aos Estados Unidos, muito pelo contrário, justamente porque os estudos sobre a literatura escrita por mulheres já se consolidou no Brasil é que já se pode pensar num posicionamento sobre o humor nessa literatura, até mesmo por uma razão muito óbvia: é impossível que nela não exista humor. $\mathrm{O}$ problema é que ver esse humor depende de acreditar, primeiro, que o humorístico é uma forma de expressão tão legítima quanto à seriedade $^{228}$ e, segundo, que as mulheres são capazes de fazê-lo.

A razão, portanto, para isso ainda não ter sido feito no Brasil, talvez passe pelo que Regina Barreca diz a propósito da ausência de estudos críticos sobre o humor escrito por mulheres até uma determinada época nos Estados Unidos: a crítica feminista evitou discutir a comédia talvez para ser aceita pela crítica conservadora que inicialmente achava a crítica feminista já cômica por si só ${ }^{229}$.

Embora, como já se disse, uma bibliografia sobre a relação entre a mulher e a literatura no Brasil tenha sido reunida, ela não será utilizada além do que já foi mencionado. Embora todos estes temas - mulheres escritoras, ensaístas, jornalistas; resgate de diários, cartas e outros escritos femininos, ou mesmo estudos sobre o humor e a ironia de Machado ou de Guimarães Rosa escritos por mulheres - sejam

227 LOBO. L. Literatura feminina na América Latina.[S.1.], [199-]. Disponível em:

< http://members.tripod.com/ lfilipe/LLobo.html >. Acesso em: 31 ago. 2004. p. 22.

228 Cf. MENDES, 2001, p. 12.

229 BARRECA, 1988, p. 5. 
muito interessantes, mencioná-los aqui significaria apenas encobrir a lacuna, a falta, a ausência de discussão sobre mulher e humor no Brasil. Ausência esta que deixada descoberta, exposta, incompleta, talvez seja, por isso mesmo, muito mais eloquente.

\section{A lacuna na prática}

O que está sendo chamado de "lacuna na prática" é a ausência de nomes de mulheres em antologias, coletâneas, enciclopédias e revistas especializadas em humor no Brasil. Em virtude de alguns autores de humor serem ao mesmo tempo escritores e cartunistas, como é o caso de Ziraldo, Millôr, Henfil, Luís Fernando Veríssimo, considerou-se pertinente o levantamento de nomes femininos também em obras de referência ligadas ao humor gráfico, como tiras, charges e caricaturas. Foram compiladas, até o momento, 12 obras com o seguinte resultado:

a. História da caricatura no Brasil, v. 1 (2012), de Luciano Magno230: nenhuma mulher.

b. Imprensa, humor e caricatura: a questão dos estereótipos culturais (2011), organizado por Isabel Lustosa ${ }^{231}$. Dos 22 artigos sobre caricatura, piadas, quadrinhos que compõem a obra, 7 tratam dessas questões no contexto brasileiro, citando, eventualmente, artistas gráficos ligados ao humor, como Henfil, Laerte, Lan, etc., mas nenhuma mulher;

c. Entre sem bater (2004), de Luís Pimentel: 93 humoristas; 1 mulher, Nair de Teffé;

d. Piracicaba 30 anos de humor (2003): 189 humoristas; 7 mulheres;

e. Barão de Itararé: o humorista da democracia (2002), de Leandro Konder: 15 humoristas; nenhuma mulher;

230 MAGNO L. História da caricatura no Brasil. Rio de Janeiro: Gala Edições de Arte, 2012. v. 1.

231 LUSTOSA, I. (Org.). Imprensa, humor e caricatura: a questão dos estereótipos culturais. Belo Horizonte: Ed. UFMG, 2011. 
f. Raízes do riso: a representação humorística na história brasileira: da Belle Epoque aos primeiros tempos do rádio (2002), de Elias Thomé Saliba ${ }^{232}$ : 51 humoristas; nenhuma mulher.

g. Os 100 melhores contos de humor da literatura universal (2001), de Flávio Moreira da Costa (Org.): 21 escritores brasileiros; 1 mulher;

h. Revista Bundas, ano 1, número 1 (1999): 36 colaboradores representantes da "nata do humor e do jornalismo brasileiro"; nenhuma mulher;

i. Antologia brasileira de humor ${ }^{233}(1976)$ [por] Adail [e outros]: 2 mulheres, Ciça e Mariza;O melhor do Pasquim 1969/70: 31 colaboradores, nenhuma mulher.Antologia de Humorismo e Sátira (1969), de R. Magalhães Jr. (Org.): 132 autores brasileiros; 04 mulheres;

j. As melhores histórias de humor de todos os tempos 234 , (197?), de Mariano Torres (Org.): 8 autores brasileiros; nenhuma mulher.

Tomando por base essas publicações, a participação feminina na produção de textos de humor no Brasil é insignificante. Luís Pimentel, em Entre sem bater, traça a história do humor na imprensa brasileira, do Barão de Itararé ao Pasquim21, e homenageia 93 escritores, redatores e roteiristas de humor, cartunistas, chargistas, caricaturistas e autores de histórias em quadrinhos ${ }^{235}$. Observa-se que, entre essas figuras de destaque do cenário humorístico nacional, há apenas uma mulher incluída, que é a cartunista Nair de Teffé.

Na biografia de Aparício Torelli, Barão de Itararé: o humorista da democracia, tido como o pioneiro do humor nacional, Leandro Konder cita nomes de humoristas que, desde o Barão, têm mantido em alta a

232 SALIBA, E.T. Raízes do riso: a representação humorística na história brasileira: da Belle Epoque aos primeiros tempos do rádio. São Paulo: Companhia das Letras, 2002.

233 ADAIL, J. P. Antologia brasileira de humor. Porto Alegre: 1976. 2v.

234 TORRES, M. (Org.). As melhores histórias de humor de todos os tempos. Rio de Janeiro: Ediouro, [197?]. (Clássicos de Bolso).

235 PIMENTEL, 2004. 
tradição de humor no Brasil. Encontram-se aí Millôr Fernandes, Sérgio Porto, Claudius, Jaguar, Fortuna, Luís Fernando Veríssimo, Paulo Gonçalves, Carlos Eduardo Novaes, Henfil, Ziraldo, Dias Gomes, Vasques, Jorge Braga, Nani, Angeli, sem que haja menção a nomes femininos ${ }^{236}$.

Na enciclopédia Literatura em quadrinhos no Brasil, o acervo da Biblioteca Nacional, os autores traçam a história do quadrinho brasileiro, de 1867, com Ângelo Agostini, até 2002. Nesse universo, aparecem os nomes de apenas três mulheres ${ }^{237}$.

Ainda no âmbito das artes gráficas, vale mencionar a coletânea Piracicaba 30 anos de humor, que reúne os cartuns, charges, caricaturas e quadrinhos premiados em cada uma das 30 mostras anuais de desenho de humor realizadas em Piracicaba. Ao todo são 189 artistas premiados, sendo que, apenas, 7 são mulheres ${ }^{238}$.

Essa presença rarefeita de nomes femininos no humor gráfico foi registrada também em um texto de Zé Roberto Graúna, intitulado Viva o Dia Internacional da Mulher!. Ele diz que pesquisa e compila nomes de artistas gráficos brasileiros desde a década de 1980, entre eles desenhistas, caricaturistas, cartunistas, ilustradores de jornais e livros e internautas que mantêm seus trabalhos na rede, classificando-os em ordem alfabética. Suspeitando que, nessa lista, os nomes masculinos eram maioria, ele resolveu dividi-la por sexo e constatou o que já desconfiava, dos mais de mil profissionais catalogados, pouco mais de uma centena eram mulheres, sendo que a maioria delas atua quase exclusivamente no mercado editorial infanto-juvenil. No campo do humor gráfico, o número se reduz drasticamente, ele cita Rian, Hilde, Yolanda, Mariza, Ciça e Pryscilla Vieira ${ }^{239}$.

Quanto às antologias de textos de humor que foram citadas, vão destacar-se, respectivamente, a mais recente e a mais antiga. Em Os 100 melhores contos de humor da literatura universal, organizada por

236 KONDER, L. Barão de Itararé: o humorista da democracia. São Paulo: Brasiliense, 2002. (Encanto Radical).

237 MOYA, Álvaro et al. (Org.). Literatura em quadrinhos no Brasil: acervo da Biblioteca Nacional. Rio de Janeiro: Nova Fronteira: Fundação Biblioteca Nacional, 2002.

238 PIRACICABA 30 anos de humor. São Paulo: IMAG: Imprensa Oficial do Estado, 2003.

239 GRAUNA. Z. G. Viva o Dia Internacional da Mulher!, [200-?]. Disponível em: <http//bp1. blogger.com/>. Acesso em: 14 mar. 2008. 
Flávio Moreira da Costa, dos 78 nomes de autores compilados, há apenas 4 mulheres; e dos 21 textos de autores brasileiros citados, há apenas 1 mulher, Zulmira Ribeiro Tavares. Há, também, na introdução do livro, uma menção ao nome de Clarice Lispector com a explicação de que ela não consta entre os compilados por uma questão de direitos autorais ${ }^{240}$.

Na apresentação da Antologia de humorismo e sátira, de R. Magalhães Junior, o autor diz que a sátira e o humorismo são expressões não apenas literárias, mas reflexos do próprio caráter do povo brasileiro, o que pode ser visto nas anedotas das ruas, nas piadas anônimas, nas tiradas ferinas com que o homem do povo alveja os poderosos. Segundo ele, sua antologia representa o mais completo balanço até então empreendido nos domínios do humorismo e da sátira brasileiros ${ }^{241}$.

Sendo ou não a mais completa, essa compilação é realmente interessante, porque nela se percebe um trabalho de garimpagem do humor. Embora, e não poderia ser diferente, na lista de autores sejam mencionadas as figurinhas carimbadas de sempre, como Aparício Torelly, Millôr e Stanislaw Ponte Preta, também há nomes como Bernardo Guimarães e Casimiro de Abreu, que não são tradicionalmente associados ao humor. O objetivo do compilador, então, não é apenas encontrar e registrar o trabalho do humorista profissional, mas o humor eventualmente utilizado pelo homem e, também, pela mulher de letras. A antologia traz os nomes de Helena Morley, Rachel de Queiroz, Maria Eugênia Celso e Vera Pacheco Jordão. Embora a lista seja curta, ela é animadora porque mostra que, se for procurado, o humor poderá ser encontrado. Entretanto, a impressão que se tem observado esta antologia específica é que houve um retrocesso na participação da mulher nessas antologias. Por que se começou com quatro e hoje só se encontra uma?

A propósito desses ameaçadores, talvez inevitáveis, retrocessos em conquistas tão arduamente obtidas, vale uma digressão que permite discutir o problema de maneira mais ampla. A edição brasileira

240 COSTA, 2001.

241 MAGALHÃES JUNIOR., R. Antologia de humorismo e sátira. Rio de Janeiro: Bloch, 1969. 
da Harvard Business Review, de junho de 2008, traz um artigo intitulado Como segurar a mulher na ciência. Logo no início, lê-se que, ao contrário do que se costuma pensar, mesmo nos Estados Unidos, é grande o número de mulheres atuando como cientistas, engenheiras e tecnólogas. Ainda que em escalões inferiores das empresas, 41\% desses profissionais são do sexo feminino. O problema é que elas estão abandonando em massa tais profissões: o índice de evasão é de $51 \%$. Das razões apontadas pelo texto para o fenômeno, quatro interessam aqui: a hostilidade no ambiente de trabalho, decorrente de um machismo redobrado nesses nichos da indústria americana; a desalentadora situação de isolamento por ser a única mulher do grupo ou do escalão; o descompasso entre o ritmo no qual a mulher prefere trabalhar e o comportamento mais ousado que se costuma reconhecer e premiar nesses campos dominados pelo homem; o "mistério" que ronda o avanço profissional nessas áreas. Isolada, sem obter crédito nem reconhecimento, a mulher não consegue discernir o que a fará crescer profissionalmente e é relegada ao papel de executora ou assistente, enquanto o homem fica com os papéis mais ilustres de criador e produtor ${ }^{242}$.

Mal comparando, é como se, no que tange à atuação das mulheres, a área de exatas estivesse para as profissões assim como o campo do humor está para a literatura. E talvez a comparação não seja tão impertinente assim, haja vista as concepções tradicionais de que tanto as exatas quanto o humor privilegiam a lógica, o racional, a "inteligência pura" 243 .

Parodiando o título do artigo, no caso do Brasil, para o contexto de jornais e revistas, como Planeta Diário, Casseta e Planeta, Bundas e Pasquim, a pergunta seria: como colocar a mulher no Clube do Bolinha do humor? Há, a esse respeito, um artigo interessante de Terezinha Bittencourt, A mulher na imprensa alternativa, em que ela fala justamente do modo como a mulher é tratada e retratada no Pasquim, na década de 1970. A disparidade entre a postura alternativa e libertária do jornal

242 HEWLETT, S. A. et al. Como segurar a mulher na ciência. Harvard Business Review, São Paulo,v. 86, n. 6, p. 11-12, Jun. 2008.

243 BERGSON, 2001, p. 2-3. 
em relação à política e a posição assumidamente "tradicional" em relação à mulher gerou uma justificativa por parte dos editores. Segundo eles, o fato de a mulher - e o texto não especifica que mulher é esta - ter apoiado o golpe de 1964 e a implantação da ditadura constituía uma falta gravíssima, com isso ela passou a ser identificada com o status quo e, como tal, passou a ser alvo das críticas ${ }^{244}$.

A autora procura ser muito correta em suas críticas à postura do Pasquim relativizando, inclusive, a acusação de machista que o jornal costuma sofrer, argumentando que, se por um lado, ela era verdadeira, por outro, era muito simplificadora, pois ocultava o contexto histórico no qual a redação na época estava inserida. Além disso, apesar de adotar posições francamente desfavoráveis aos avanços da mulher, o jornal não adotava um discurso monofônico, permitindo que vozes discordantes se manifestassem ${ }^{245}$.

Em que pese o espírito democrático da redação do Pasquim, a verdade é que nunca se ouviu falar de uma colunista, articulista ou cartunista - protagonista - no jornal. E mutatis mutandis, o contexto político-social mudou de 1969 para 1999, o nome mudou de Pasquim para Bundas, mas a posição que a nata do humorismo brasileiro adota em relação à mulher continua a mesma. Nem é preciso ler, basta olhar a capa da primeira edição, lançada em 18 de junho de 1999. Nela aparece, logo abaixo do título da revista, a foto de uma mulher de costas, nua da cintura às coxas, seguida da legenda: "A nata do Humor e do Jornalismo brasileiro está dentro".

\section{Sinais de mudança}

Apesar de não tão salientes como o machismo da capa da revista, há sinais de que as coisas podem estar mudando no cenário do humor produzido por mulheres no Brasil. Há, por exemplo, uma série

244 BITTENCOURT, T. A mulher na imprensa alternativa. In: SEMINÁRIO NACIONAL MULHER E LITERATURA, 7, 1999, Niterói. Anais... Niterói: Eduff, 1999. p. Niterói: Eduff, 1999. p. 312-317. V. 1.

245 BITTENCOURT, 1999. 
de críticas, ora positivas ora negativas, na mídia impressa e digital, sobre livros e sites de humor de mulheres. Ou seja, já há uma produção de humor feito por mulheres para ser criticada. Dessa produção, foram encontradas menções aos seguintes trabalhos: 02 neurônio - Almanaque pra garotas calientes de Jô Hallack e outros ${ }^{246}$, que também estão no site 02 neurônio; Tapa de humor não dói de Suzana Abranches e outros ${ }^{247}$; Eu sento, rebolo e ainda bato um bolo, de Marcela Catunda e Andréa Cals ${ }^{248}$, que também são as criadores do site Banheiro Feminino.

Também promissores são os artigos que reconhecem o talento das mulheres para o humor, como o da autoria de Sérgio Augusto, colunista de revistas como Bundas e Bravo, que se encontra na coletânea de suas colunas, intitulada Lado B. No texto O clitóris que ousa dizer seu nome, o autor menciona o sucesso da revista de humor, Grelo Falante, e diz que aqueles que acham que a mulher não tem senso nem talento para o humor ainda não encontraram a mulher certa. E cita nomes como Dorothy Parker, Mae West e Lorrie Moore, em língua inglesa, e, no Brasil, Bárbara Gancia, Bianca Ramoneda, Elisa Palatinik e Lúcia Guimarães ${ }^{249}$.

No encarte Veja Mulher Especial, suplemento da edição da Veja, de maio de 2008, há um artigo, intitulado "E quem disse que mulher não é engraçada?”, que, como o título indica, é mais uma resposta às provocações de Christopher Hitchens. O texto, além de resumir as ideias de Hitchens e louvar sua inteligência e seu talento histriônico, pergunta como é que ele explica a recente multiplicação de mulheres na vanguarda da comédia, não apenas atuando, mas escrevendo, produzindo, interpretando e dirigindo obras de humor. Entre elas, o texto cita, na TV americana, Tina Fey (30 Rock), Sarah Silverman (com programa homônimo) e Amy Poehler e Rachel Dratch (Saturday Night Live) e, no Brasil, Ingrid Guimarães, autora (Cócegas),

246 AVELINO, P. Três livros femininos, [S.1.], [200-]. Disponível em: <www.fla.matrix.com. br/pavelino/femininos.htm>. Acesso em: 13 ago. 2004.

247 Ibid.

248 COLOMBO, S. Humor feminino sai do banheiro. Folha de S. Paulo, São Paulo,10 dez. 2006.

249 AUGUSTO, S. O clitóris que ousa dizer seu nome. In: AUGUSTO, S. Lado B. Rio de Janeiro: Record, 2001. p. 76. 
intérprete (Cócegas) e diretora de peças (Sete conto, de Luiz Miranda) e programas de humor, como Mulheres Possíveis (Canal GNT) e Sob nova direção (Rede Globo), e Grace Gianoukas, roteirista, diretora e atriz do grupo Terça Insana ${ }^{250}$. Parece que o tiro de Hitchens acabou saindo pela culatra.

Uma iniciativa dos organizadores do Salão Internacional de Humor de Piracicaba vem ao encontro dos ventos favoráveis ao humor produzido por mulheres. Em 2011, a percepção de que havia poucas mulheres entre os artistas participantes do Salão levou o Centro Nacional de Documentação, Pesquisa e Divulgação do Humor de Piracicaba (CEDHU), responsável pela produção do evento, a realizar a primeira edição da exposição Batom, Lápis e TPM. A exposição, realizada em comemoração ao Dia Internacional da Mulher, reuniu 58 obras de 25 artistas do humor gráfico para homenagear, criticar, refletir e tentar compreender a mulher contemporânea. Além de brasileiras, houve representantes de mais sete países: Argentina, Colômbia, Espanha, Irã, Itália, Japão e México.

A segunda edição da exposição aconteceu de 08 de março a 08 de abril de 2012. O número de artistas e de países participantes cresceu consideravelmente. Em 2011 participaram 25 artistas de 8 países; este ano vieram 52 artistas de 14 países, sendo que o número mais promissor vem do Brasil. Em 2012, o número de participantes brasileiras praticamente dobrou: foram 32 artistas em relação a 17 do ano anterior.

Esses números ressaltam o acerto da imagem escolhida para ilustrar o cartaz da primeira exposição, disponível no site do CEDHU, que mostra uma face de mulher sendo traçada a batom, de autoria da cartunista espanhola, Nani Mosquera. Eles levam a acreditar que o rosto da mulher, no contexto do humor gráfico brasileiro, está começando a aparecer.

250 E QUEM disse que mulher não é engraçada?. Veja, São Paulo, ano 41, n. 2.062, maio 2008. Suplemento. 
Espera-se que passem a integrar, também, o conjunto desses sinais de mudança este trabalho e a antologia virtual de contos, casos e crônicas com humor, escritos por mulheres no Brasil, que será apresentada a seguir. 